\title{
Matematik Öğretmeni Adaylarının Pergel-Cetvel ve Dinamik Geometri Yazılımı Kullanarak Yaptıkları Geometrik İnşalar
}

\author{
Fadime Ulusoy
}

Kastamonu Üniversitesi, Eğitim Fakültesi, Kastamonu/Türkiye (ORCID: 0000-0003-3393-8778)

Makale Geçmişi: Geliş tarihi: 13 Aralık 2018; Yayına kabul tarihi: 2 Şubat 2019; Çevrimiçi yayın tarihi:18 Şubat 2019

Öz: Bu araştırma, ilköğretim matematik öğretmeni adaylarının pergel ve birimsiz cetvel kullanarak paralelliği nasıl inşa ettikleri ve yaptıkları inşaları doğrulamak için kullandıkları gerekçeleri incelenmeyi amaçlamıştır. Ek olarak, dinamik matematik yazılımı (GeoGebra) kullanılan sınıf tartışmalarında öğretmen adaylarının geometrik inşaları ile ilgili fark ettikleri durumlar analiz edilmiştir. Çalışmaya ilköğretim matematik öğretmenliği programında öğrenim gören 68 öğretmen adayı katılmıştır. Veriler, yazılı dokümanlar, yansıtıcı düşünme raporları ve sınıf tartışması gibi birçok nitel araştırma veri toplama teknikleri kullanılarak elde edilmiştir. Elde edilen veriler, yapılan detaylı alan yazın taramasının 1şığında içerik analize tabii tutulmuştur. Sonuçlar, öğretmen adaylarının yaptıkları uygun paralellik inşalarında dik doğrular, açı kopyalama, eşkenar üçgen ve eşkenar dörtgen yöntemleri olmak üzere dört farklı yöntemi kullandıklarını göstermiştir. Fakat öğretmen adaylarının yarısından fazlası yaptıkları geometrik inşa sürecinde her ne kadar paralel doğrulara ait özellikleri kullanarak yola çıksalar da inşalarda hatalı varsayımlar yaptıkları için uygun olmayan paralellik inşaları elde etmişlerdir. Son olarak, öğretmen adayları GeoGebra-destekli sınıf tartışmalarında (i) alternatif inşa yöntemlerini, (ii) inşalarda sağlam dayanaklar sunmanın gerekliliğini, (iii) yanlış varsayımların geometrik inşadaki etkisini ve (iv) dinamik geometri yazılımı ve pergel-cetvelin geometrik inşa ve ispatlamadaki farklı rollerini fark etmişlerdir.

Anahtar Kelimeler: Geometrik inşa, paralellik, ilköğretim matematik öğretmeni adayı, pergel ve cetvel, dinamik matematik yazılımı, GeoGebra

DOI: $10.16949 /$ turkbilmat.496853

\begin{abstract}
This study aimed to investigate prospective middle school mathematics teachers' geometric constructions and justifications to verify their constructions when they used compass-straightedge. In addition, it was examined that what prospective teachers noticed about geometric constructions in a classroom discussion where dynamic mathematics software (GeoGebra) was used. A total of 68 prospective teachers from middle school mathematics teacher education program participated to the study. Data were obtained by qualitative research ways such as written papers, reflective notes, and classroom discussions. The data were analyzed based on content analysis. The results showed that prospective teachers used four different methods in appropriate parallelism constructions such as perpendicular lines, angle copying, equilateral triangles and rhombus methods. Another important result was that more than half of the prospective teachers did not achieve the appropriate geometric constructions because they made incorrect assumptions in the geometric constructions. Finally, prospective teachers noticed following issues in GeoGebra-supported classroom discussions: (a) alternative construction methods, (b) the necessity of providing solid foundations, (c) the effect of incorrect assumptions in geometric constructions and (d) different roles of dynamic geometry software and compass-straightedge in the process of geometric constructions and justifications.
\end{abstract}

Keywords: Geometric construction, parallelism, prospective middle school mathematics teachers, compass and straightedge, dynamic mathematics software, GeoGebra

See Extended Abstract

Sorumlu yazar: Fadime Ulusoy iD e-posta: fadimebayik@gmail.com

Kaynak Gösterme: Ulusoy, F. (2019). Matematik öğretmeni adaylarının pergel-cetvel ve dinamik geometri yazılımı kullanarak yaptıkları geometrik inşalar. Türk Bilgisayar ve Matematik Eğitimi Dergisi, 10(2), 336-372. 


\section{Giriş}

Matematikte kavramların öğrenilmesinde, bilginin oluşumunda ve problemlerin çözümünde öğretim materyalleri önemli rol oynamaktadır (Hiebert ve ark., 1997). Bu konuda yapılan birçok araştırma, öğrenme süreçlerinde materyallere yer vermenin öğrenmeyi kolaylaştırdığını ve aktif bir öğrenme ortamı sunarak öğrencilerin güdülenmesine ve yaratıcılıklarının gelişimine yardımcı olduğunu vurgulamaktadır (İşman, 2005; Knapp \& Glenn, 1996). Öğretim materyallerinin kavramsal süreci anlamlandıracak biçimde kullanılması, kavramların anlaşılması ve materyalin amaca hizmet etmesi bakımından önem taşır (Karakuş, 2014). Bu nedenle, materyallerin öğrenme ortamında planlı ve uygun rehberlik ile birlikte kullanılması gerekir (SpearSwerling, 2006). Matematik öğretiminde birim küpler, taban blokları ve geometrik şekil modelleri gibi fiziksel materyallere sıklıkla yer verilirken, pergel, cetvel ve açıölçer gibi materyallerin kullanımı ve kullanımın öğrenmeye etkileri ile ilgili sınırlı sayıda çalışmaya rastlanmaktadır (ör., Karakuş, 2014). National Council of Teachers of Mathematics (NCTM, 2000) standartlarında farklı materyaller kullanılarak geometrik şekillerin oluşturulmasının anlamlı öğrenme ile olan ilişkisinde geometrik inşa çalışmalarının önemi açıkça vurgulanmaktadır. İlköğretim 6-8. sınıf matematik öğretim programında pergel kullanımına ve her sınıf düzeyinde temel geometrik inşalara yönelik kazanımlara yer verilmektedir (MEB, 2009). Yenilenen ilköğretim matematik öğretim programında (Milli Eğitim Bakanlığı [MEB], 2018) geometrik şekillerin çizimi ile ilgili kazanımlara yer verilmektedir. Programda açıkça pergel ve cetvel kullanımından bahsedilmese bile teknolojik uygulamalar ve noktalı-kareli kağıt kullanımı ile yapılacak inşa çalışmaları vurgulanmaktadır. Ayrıca Milli Eğitim Bakanlığı tarafından onaylanan matematik kitaplarında, pergel-cetvel kullanımı ile açırtay, eş açılar, diklik ve üçgen inşası gibi temel inşalar bulunmaktadır (ör., Bektaş, Kahraman ve Temel, 2018). Bazı kitaplarda, GeoGebra ve Sketchpad gibi dinamik yazılımlarla elde edilmiş geometrik inşa örnekleri de yer almaktadır (Böge ve Akıllı, 2018). Bu bakımdan, geometrik inşa çalışmalarının, pergel-cetvel veya dinamik yazılımların kullanımı ile ülkemizdeki ilköğretim matematik ders kitaplarında önemsenen bir konu olduğunu söyleyebiliriz.

Uzun yıllardan beri okullarda geometri öğretim sürecinde kullanılan Öklid geometrisinin barındırdığı aksiyomatik sistemde geometrik şekil inşaları büyük bir öneme sahiptir (Lim-Teo, 1997; Smart, 1993). Bu nedenle, Öklid geometrisi bir pergel ve birimsiz cetvel aracılığıyla çizilebilen şekillerin geometrisi olarak da kabul edilmektedir (Axler \& Ribet, 2005; Stillwell, 2005). Geometrik inşalar, doğrudan ölçme imkânının olmadığı durumlarda istenen geometrik şeklin oluşumunda etkin rol oynar (Freeman, 2010). Geometrik inşa çalışmalarında amaç, pergel ve birimsiz cetvel kullanarak bir prosedürü uygulayıp belli şekilleri elde etmekten ziyade geometrik bir probleme çözüm bulmaktır (Erduran ve Yeşildere, 2010; Napitupulu, 2001). Bu yönüyle, geometrik inşalar geçmişten günümüze matematikçilerin ilgisini çekmekle birlikte bir problem durumu olarak kabul görmüştür (Freeman, 2010). Öklid geometrisinde yer alan temel çizimler için birçok örnek vardır (Smart, 1993). Bunlar, bir doğru parçasına eş bir doğru parçası inşa etme, bir doğru parçasını iki eş parçaya ayırma, bir doğruya dışındaki/üzerindeki bir noktada paralel/dik doğru inşa etme, bir açıya eş iki açı inşa etme, bir açının açırtayını 
oluşturma ve çembere teğet bir doğru oluşturma gibi birçok örnekle çoğaltılabilir. Birimsiz cetvel ve pergel ile yapılan inşalarda, bireyin hem materyalleri psiko-motor becerilerini devreye sokarak iyi kullanması hem de inşa sürecinin nasıl gerçekleşeceğini bilişsel olarak anlaması gerekir (Altun, 2015; Erduran ve Yeşildere, 2010). Böylece bir geometrik yapının pergel ve ölçüsüz cetvel kullanılarak inşa edilmesi, öğrencilerin birçok geometrik özelliği anlamasına yardımcı olmaktadır ve çizimleri nasıl yapacakları hakkında tahmin yürütmelerini sağlamaktadır (Cheung, 2011). Çünkü inşa çalışmalarına nereden başlanması gerektiğine ilk başta karar verilememesi bir problem durumu oluşturmaktadır ve matematiksel becerilerin kullanılmasını zorunlu kılmaktadır (Erduran ve Yeşildere, 2010). Böylece, geometrik inşa çalışmaları ile öğrenciler analiz, değerlendirme, hipotez kurma ve organize etme gibi üst düzey düşünme becerilerini kullanarak öğrendiği birçok kavramı ve özelliği uygulama firsatı elde eder (Lim-Teo, 1997). İnşa sürecinde karşılaşılan güçlükler sayesinde problem çözücüler neyin eksik ya da yanlış olduğunu fark eder ve birçok farklı geometrik şekil arasındaki ilişkiyi keşfederek problemi çözmek için farklı yollara başvurabilir (Napitupulu, 2001; Posamentier, 2000).

Geometri öğrenme alanındaki kavramların, temel kavramlar üzerine inşa edildiğini söyleyebiliriz. Örneğin, öğrencilerin üçgen tanımını anlaması için kapalılık, açı, kenar ve köşe kavramlarını bilmesi gerekir. Benzer şekilde, Öklid geometrisinde paralellik ve diklik kavramları da öğrencilerin yükseklik, orta dikme, kenarortay, dik açı ve dörtgen özelliklerini, koordinat sistemini anlamada kritik önem taşır ve ispatlama, argümantasyon ve genelleme becerilerini harekete geçirilmesinde etkin rol oynar (Mansfield \& Happs, 1992). Öğrencilerin paralellik ve diklik ile kavrayışları üzerine yapılan çalışmalar, öğrencilerin bu kavramları çizerken ve paralel ve dik doğru parçalarını belirlerken hata yaptıklarını ortaya çıkarmıştır (Abravanel, 1977; Gal, 2011; Ulusoy, 2016; Ulusoy ve Çakıroğlu, 2017). Örneğin, Mansfield ve Happs (1992), paralellik ile ilgili yaptığ1 çalışmada (i) eğik duran paralel doğru parçaları, (ii) kağıtta uzatıldığında potansiyel kesişim noktası olan doğru parçaları, (iii) aralarında eşit uzaklık olmayan doğru parçaları ile verilen üç durumun varlığında çocukların paralelliği belirlemede problem yaşadığını belirtmiştir. Çalışmalarda öğrencilerin özellikle dikey/yatay konumda bulunmayan doğru parçalarında paralelliği tespit etmede zorlandıkları belirtilmektedir (Mitchelmore, 1992). Örneğin, Ulusoy (2016) bazı ortaokul öğrencilerinin dikey konumda duran paralel doğru parçalarının birbirine dik olduğunu iddia ettiği, bazılarının ise bu doğru parçalarının birbirine hem paralel hem de dik olduğunu belirttiği sonucuna varmıştır.

Öğrencilerin kavrayışları, öğretmenlerin derslerinde kavramları nasıl ele aldıklarıyla ilgilidir. Öğretmenlerden temel geometrik çizimlerin öğretilmesinin beklendiği, gerek ilköğretim matematik öğretim programında gerek ortaokul ders kitap içeriklerinde açıkça vurgulanmaktadır. Fakat öğretmenlerin bu becerileri öğrencilere kazandırmaları, onların geometrik inşalarla ilgili bilgi ve becerilerinin yeterli olmasıyla mümkün olabilir. $\mathrm{Bu}$ farkındalıkla, son yıllarda ülkemizde geometrik inşalarla ilgili öğretmenlerin ve öğretmen adaylarının düşüncelerini, tutumlarını ve başarılarını anlama adına çalışmalar gerçekleştirilmiştir. Yapılan çalışmalar, genel anlamda öğretmenlerin/öğretmen adaylarının pergel-cetvel inşalarını kullanmaya karşı olumlu tutum sergilemelerine rağmen inşa süreçlerinde ezberci bir yol aldıklarını veya istenen inşayı oluşturmada 
yeterince başarılı olamadıklarını ortaya çıkarmıştır (Bozkurt, 2018; Çiftçi ve Tatar, 2014; Erduran ve Yeşildere, 2010; Gür ve Kobak-Demir, 2017; Öçal ve Şimşek, 2017). Bu araştırmalar, öğretmen adaylarının bu konuda eksikliklerinin varlığını ve bu eksiklerin giderilmesi gerektiğini göstermektedir. Fakat belirtilen araştırmaların birçoğunda, öğretmen adaylarının geometrik inşa süreçleri ve bu süreçte ürettikleri matematiksel gerekçelere kavramsal boyutta ve derinlemesine odaklanmak yerine daha çok onların tutum ve görüşlerine odaklandıkları dikkat çekmektedir. Bu eksiklik, öğretmenlerin inşa süreçlerinde geometri konularında kavrayışlarına ve gerekçelerine odaklanarak onların daha donanımlı hale gelmelerine yardım edecek içeriklerin hazırlanmasına olan ihtiyacı yansıtmaktadır. Bu noktada, öğretmen eğitimi programları öğretmen adaylarına geometrik inşa becerilerini ve bilgilerini edinebilecekleri ortamları yaratmak için en uygun yerlerden biridir. $\mathrm{Bu}$ nedenle, bu araştırmada, ilköğretim matematik öğretmeni adaylarının öğrencilerin büyük sıkıntı yaşadıkları temel geometrik kavramlardan biri olan paralellik ile ilgili pergel-cetvel ile yaptıkları geometrik inşalar derinlemesine incelenmiştir. Ayrıca bu araştırmada, öğretmen adaylarının GeoGebra kullanılarak yapılan sınıf tartışmasında geometrik inşalarla ilgili neleri fark ettiklerine odaklanılmıştır. $\mathrm{Bu}$ doğrultuda, bu araştırmada şu sorulara cevap aranmıştır:

(1) İlköğretim matematik öğretmeni adayları birimsiz cetvel ve pergel kullanarak paralelliği nasıl ve hangi yöntemlerle inşa etmişlerdir?

(2) Öğretmen adayları dinamik matematik yazılımı (GeoGebra) destekli bir ortamda gerçekleşen sınıf tartışmalarında geometrik inşa ve gerekçelendirme süreçleriyle ilgili neleri fark etmişlerdir?

$\mathrm{Bu}$ araştırmada inşa süreçlerinde pergel-cetvel kullanımına ek olarak GeoGebra programı belli nedenlerden dolayı tercih edilmiştir. GeoGebra, geometri ve cebir öğrenme alanlarını tek bir ara yüz üzerinde taşıyan açık kaynak kodlu (ücretsiz), Java tabanlı olmasından ötürü geniş spektrumlu bir platformda çalışan bir matematik yazılımıdır (Dikovich, 2009). GeoGebra, kullanım kolaylığı, ücretsiz olması ve çeşitli dillere çevrilmesi nedeniyle matematik ve geometri öğretiminde önemli bir yere sahiptir (Baltacı, Yıldız \& Kösa, 2015; Kutluca ve Zengin, 2011). Yazılım içeriğinde noktalar, doğrular, çemberler, inşalar, ölçümler ile ilgili birçok ikon bulunmaktadır. Bu yönüyle yazılım, geometrik kavramların görselleştirilmesinde ve inşasında önemli işlevleri yerine getirebilme özelliği taşımaktadır. Belirtilen avantajlar ve kullanım uygunluğu, çalışmada GeoGebra yazılımının kullanılma nedenlerinden birisi olmuştur. Ayrıca yapılan çalışmalar, öğretmen adaylarının GeoGebra aracılığıyla önceden bilgi sahibi oldukları konuları yeniden anlamlandırdıklarını ve derinleştirdiklerini (Tatar, 2013) ve matematiksel ilişkileri fark edebildiklerini (Bu \& Haciomeroglu, 2010) ortaya çıkarmıştır. Fakat bazı çalışmalar öğretmenlerin (adaylarının) Geogebra kullanımı konusunda olumlu görüş sunsalar bile derslerine entegre etme konusunda çekimser veya endişeli davrandıklarını ortaya çıkarmıştır (Mainali \& Key, 2012). Bu yönde, öğretmen adayları üniversitede aldıkları eğitimin GeoGebra yazılımını derslerine entegre etmede yeterli bulmadıklarını belirtmişlerdir (Tatar, 2013). Belirtilen çalışmaların ışığında, bu araştırmada GeoGebra yazılımının kullanımının hem öğretmen adaylarının ilgili geometri konusunda derinleşmelerine, hem de üniversite eğitiminin erken bir döneminde yazılımla 
tanışmaları sağlanarak onların yazılımla ilgili olumlu düşünce geliştirmelerine ve yazılımı öğretimsel süreçlerinde kullanma bakımından motive olmalarına yardımcı olacağ düşünülmektedir.

\subsection{Geometrik İnşalarla İlgili Yapılan Çalışmalar}

Smart (1993) geometrik inşa problemlerinin çözümü için gereken adımları analiz, inşa etme, ispat ve tartışma olarak ele almıştır. Analiz aşamasında, öğrenciler problemde istenen durumu gerçekleştirdiğini varsayarak istenen şeklin çizimini yapar ve çizim için gereken bilinmeyen durumlarla problemde verilen durumları ilişkilendirir. İnşa aşamasında, öğrenci pergel ve ölçüsüz cetvel yardımıyla izler üzerinden çizimini gerçekleştirir. İspat aşamasında ise, inşa edilen yapının istenen duruma uygun olup olmadığını incelenerek ispat yapar. Son olarak, tartışma aşamasında öğrenci problemin çözümünde kullanılacak muhtemel çözüm yollarını tartışır. Benzer şekilde, Duval (1998) geometrik öğrenmede görselleştirme, inşa ve muhakeme olarak üç önemli bilişsel sürecin devrede olduğunu belirtmiştir. Belirtilen bu çalışmalarda inşa problemi için önerilen adımlar, geometrik inşa çalışmalarının öğrencilere teknolojik ya da fiziksel öğrenme materyallerini kullanma becerisi kazandırmayı ana hedef olarak görmediğini göstermektedir. Aksine, bu adımlar, bireylerin inşa edilen geometrik yapının özelliklerini ve oluşumunu derinlemesine analiz etmesi gerekliliğine vurgu yapmaktadır (Cherowitzo, 2006).

Öğretmenlerin veya öğretmen adaylarının pergel-cetvel ile veya pergel-cetvel özelliği olan dinamik geometri yazılımları ile geometrik inşaları nasıl yaptıklarını ve tutumlarını konu alan çalışmaların sayısında son yıllarda artış olduğu dikkat çekmektedir (Bozkurt, 2018; Çiftçi ve Tatar, 2014; Erduran ve Yeşildere, 2010; Gür ve Kobak-Demir, 2017; Öçal ve Şimşek, 2017). Ayrıca, geometrik inşalarla ilgili bazı çalışmalarda öğrencilerin yaptıkları inşalar ile van Hiele geometrik düşünme düzeyleri arasındaki ilişkilere odaklanıldığ1 tespit edilmiştir (Cheung, 2011; De Villiers, 2003; Napitupulu, 2001; Güven, 2006). Örneğin, geometrik inşa çalışmaları ve van Hiele düşünme düzeyleri ilişkisinin incelendiği bir araştırmada, Napitupulu (2001) Endonezya'da 34 öğretmen adayının geometrik düşünme düzeylerini belirledikten sonra Geometers' Sketchpad programını kullanarak dik doğrular, paralel doğrular, orta dikme, bir açıya eş açı, açırtay çizme gibi konularda 7 haftalık bir öğretim tasarımını uygulamıştır. Çalışma sonuçları, geometrik inşa çalışmalarının öğretmen adaylarının Van Hiele geometrik düşünme düzeylerini pozitif anlamda etkilediğini göstermiştir.

$\mathrm{Bu}$ araştırmanın içeriği ve amacı düşünüldüğünde, öğretmenler ve öğretmen adaylarının geometrik inşa süreçlerini ele alan çalışmaları incelemek geometrik inşalarla ilgili düşünceleri ve yaşanan problemleri anlamak açısından önemlidir. Örneğin, Erduran ve Yeşildere (2010) üç ilköğretim matematik öğretmeniyle yaptıkları nitel araştırmada öğretmenlerin derste pergel-cetvel kullanımına pozitif bakmalarına rağmen derslerini öğretmen-merkezli ve geometrik inşa aşamalarını sorgulamadan uzak ele aldıkları sonucuna varmışlardır. Diğer taraftan, Karakuş’un (2014) 63 ilköğretim matematik öğretmeni adayının geometrik inşalarla ilgili görüşlerini incelediği çalışmada, öğretmen adaylarının birçoğu daha önce pergel ve cetvel kullanarak çizim yapmadıklarını ve 
geometrik kavramların formülleri ezberleyerek öğrendiklerini dile getirmişlerdir. Diğer önemli bir sonuç ise, birçok öğretmen adayı sadece kurallara göre çizim yaptıklarını belirtmelerine rağmen pergel-cetvel inşalarının faydalı olduğunu söylemişlerdir. Ayrıca araştırmac1, öğretim sürecinde geometrik inşalara yer verilmemesini (1) sinıflarda öğretim materyallerini kullanmayı tercih etmeme, (2) öğretmenlerin inşa aktiviteleri ile ilgili bilgi ve tecrübe eksiklikleri ve (3) inşa çalışmalarıyla öğretim programı arasındaki kopukluklar olarak belirttiği üç nedene bağlamıştır. Öçal ve Şimşek' in (2017) dört ortaokul matematik öğretmeniyle yaptıkları nitel bir çalışmada da bazı benzer sonuçlara varılmıştır. $\mathrm{Bu}$ araştırmada, öğretmenlerin pergel-cetvel ve dinamik yazılımlarını kullanarak temel geometrik inşa problemlerini nasıl çözdükleri ve bu konudaki görüşleri ele alınmıştır. Araştırma sonuçlarında, öğretmenlerin Türkiye'deki sınıf sistemi ve dersleri yetiştirememe kaygısı nedeniyle pergel-cetvel inşalarına derslerinde hiç yer vermedikleri veya çok yüzeysel ele aldıklarını göstermiştir. Diğer bazı çalışmalarda olduğu gibi (Erduran ve Yeşildere, 2010; Gür ve Kobak-Demir, 2017; Karakuş, 2014), bu araştırmada da öğretmenlerin pergel-cetvel inşalarında başarılı olmamalarına rağmen bu etkinlikleri öğretici ve eğlenceli gördükleri ortaya çıkmıştır. Ayrıca araştırmacılar GeoGebra ile yapılan inşalarda uygulamanın deneme-yanılma firsatı vermesi nedeniyle pergel-cetvelle yapılan inşalardan farklı olarak inşa aşamalarında daha sıralı bir yaklaşım sergilediklerini göstermiştir. Dinamik geometri yazılımının kullanıldığı bir diğer çalışmada, Bozkurt (2018) 71 öğretmen adayının pergel ve cetvel özelliği olan The Geometer's Sketchpad programında yaptıkları inşaların doğruluğunu ve bu süreçte ürettikleri gerekçeleri incelemiştir. Sonuçlar, öğretmen adaylarının inşa performanslarının düşük olduğunu ve yaptıkları inşalarla ilgili sınırlı gerekçeler sunduklarını ortaya çıkarmıştır. Diğer yandan, Çiftçi ve Tatar (2014) yaptıkları araştırmada doğrular ve açılarla ilgili inşalarda pergelcetvel kullanma ile dinamik bir yazılım kullanmanın öğretmen adaylarının başarılarına etkilerini karşılaştırmayı ve kullanılan öğretim materyali ile ilgili düşüncelerini ortaya çıkarmayı amaçlamıştır. Çalışma sonuçlarında ise pergel-cetvel kullanan grubun başarısı ile dinamik geometri yazılımı kullanarak inşa gerçekleştiren grubun başarısı arasından anlamlı bir fark olmadığını bulmuşlardır. Ayrıca araştırmacılar hem pergel-cetvel hem dinamik yazılım kullanmanın öğretmen adaylarının başarılarına olumlu yönde katkı sağladığı sonucuna varmışlardır. Bahsi geçen araştırma sonuçları göz önünde bulundurularak, bu araştırmada öğretmen adaylarının pergel-cetvel kullanarak ürettikleri paralellik inşaları ele alındıktan sonra seçilen bazı inşalar sınıf ortamında GeoGebra kullanılarak yeniden inşa edilmiş ve tartışılmıştır. Bu noktada, çalışmanın amacı öğretim materyallerinin etkililiğini kıyaslamak değildir. Amaç, öğretmen adaylarının inşa sürecinde farklı öğrenme araçlarını kullanmalarını sağlamak ve bu süreçte onların paralellik inşası ve ispatı ile ilgili geometrik düşüncelerini ele almaktır.

\section{Yöntem}

Durum çalışmaları, kişi, sınıf veya toplumun karakteristik özelliklerinin niçin-nasıl soruları ile ele alınarak derinlemesine analiz edilmesini sağlayan nitel bir araştırma yöntemidir (Cohen, Manion \& Morisson, 2002). Durum çalışmaları arasında tekli durum çalışmalarında tek bir birey ya da benzer özelliklerde olan bir grup birim olarak kabul edilip incelenir ve böylece aynı durum içinde oluşan farklılıklara alternatif açıklamalar 
sunulabilir (Yin, 2013). Öğretmen adaylarının yaptıkları geometrik inşalar ile ilgili durumların bütüncül olarak incelenmesi, tekli durum çalışması özelliği gösterdiği için bu araştırmada bütüncül tekli durum çalışması deseni benimsenmiştir. Bu sayede, öğretmen adaylarının yaptıkları inşalardaki farklılıklara alternatif açıklamalar sunulmuştur.

\subsection{Katılımcilar}

$\mathrm{Bu}$ araştırmanın katılımcıları, Türkiye'de bir devlet üniversitesinin ilköğretim matematik öğretmenliği programının birinci sınıfının ikinci eğitim-öğretim döneminde öğrenim gören ve Geometri dersine kayıtlı olan 68 öğretmen adayından oluşmuştur. Katılımcılardan daha detaylı veriler toplamak amaçlandığ 1 için kolay ulaşılabilir örnekleme yöntemi tercih edilmiştir. Katılımcılar, verilerin toplandığg dönem içinde ve daha önceki dönemlerde pür matematik derslerinden Genel Matematik ve Soyut Matematik derslerini almışlardır. Öğretmen adaylarının yaptıkları inşa ve gerekçelerdeki çeşitlilik bütüncül olarak değerIendirilmek istendiği için Geometri dersini alan 68 öğretmen adayının tümü (19 erkek ve 49 kadın) çalışmanın katılımcıları olarak belirlenmiştir.

\subsection{Verilerin Toplanması}

Veriler, toplamda iki grup halinde olan 68 öğretmen adayından 14 hafta olarak planlanan geometri dersinin sekizinci ve dokuzuncu haftasında toplanmıştır. Verilerin toplanmasından önce geçen yedi haftalık süreçte Öklid geometrisinin aksiyomatik yapısı, belli geometrik kavramların tanımları ve ilgili teoremler ele alınmıştır. Özellikle beşinci, altınc1 ve yedinci haftalarda pergel-cetvel ile temel geometrik çizimler yapılmıştır. $\mathrm{Bu}$ kapsamda, öğretmen adaylarıyla birlikte doğru parçası taşıma, eşkenar üçgen çizimi, verilen bir doğrunun orta noktasını bulma, açı taşıma, açıortay çizme, bir doğruya üzerindeki ve dışındaki noktalardan dikme çizme etkinliklerine yer verilmiştir. Fakat paralel doğruların inşası bu süreçte öğretmen adaylarına gösterilmemiştir. Dersin dördüncü haftasında geometrik inşa etkinliklerine başlamadan önce öğretmen adaylarına cetvel ve pergel kullanarak geometrik şekil inşalarını daha önce yapıp yapmadıkları sorulmuştur. Öğretmen adaylarının oldukça büyük bir çoğunluğu daha önceki öğrenim süreçlerinde pergel-cetvel ile inşa çalışmaları yapmadıklarını belirtmişlerdir. Bu nedenle, ilk birkaç çizimde geometrik inşaların pergel ve cetvel ile nasıl yapıldığından bahsedilmiştir. Araştırmacı tahtada pergel ve cetvel kullanarak basit inşalara başlamıştır. Geometrik inşa çalışmalarında araştırmacı öğretmen adaylarından öncelikle kağıt kalem ortamında belli denemeler yapmalarını istemiştir. Ardından, sınıfta öğretmen adayları yaptıkları inşaları paylaşmışlar ve onlar üzerinde tartışmalar gerçekleştirmişlerdir. Daha sonra tahtada inşa tekrar edilmiş ve aşamalı olarak inşa adımları yazılmıştır. Bu noktada, öğretmen adayları inşada izlenen adımları aşamalı halde yazmaları konusunda desteklenmiştir. İnşa sürecinin aşamalar halinde yazılması, yapılan geometrik inşanın gerekçelendirildiği anlamına gelmediğinden yapılan geometrik inşa sonunda istenen şekle ulaşılıp ulaşılmadığından nasıl emin olduklarını açıklamaları istenmiştir. Tüm geometrik çizimlerde benzer yollar izlenmiştir. Ek olarak, veriler toplanmadan bu yedi haftalık ders sürecinde geometrik inşaların bazıları GeoGebra programının temel özellikleri öğretildikten sonra öğretmen adaylarıyla birlikte yazılımda tekrar inşa edilerek 
doğrulamalar yapılmıştır. Bu konuda, ilk olarak GeoGebra yazılımındaki geometri içerikli özelliklerden detaylı biçimde bahsedilmiştir. Noktalar, doğru, üçgen, çokgenlerin oluşturulması ve inşa ikonu altında yer alan özelliklerin (ör., dikme, paralellik) tümü sınıfta ele alınmıştır. Dikliğin açı ile kontrol edilmesi ve uzaklık ölçümü ile ilgili özellikler açıklanmıştır. Sonrasında, öğretmen adaylarıyla birlikte orta dikme, diklik, çemberlerin kesişimi vb. durumlar yazılımda sınıf̧̧a denenmiştir. Yazılım ile ilgili uygulamalara veri toplamadan önce yaklaşık 10 ders saatinin belli kısımlarında yer verilmiştir. Bu sayede, öğretmen adaylarının veri toplama sürecine başlamadan önce hem pergel-cetvel kullanımına hem de GeoGebra yazılımının geometri ve inşa ile ilgili özelliklerini kullanmaya alışması sağlanmıştır. Böylece verilerin toplanacağı haftada tecrübe eksikliğinden kaynaklanacak problemli durumların oluşumu engellenmeye çalışılmıştır.

Dersin ilk yedi haftasında edinilen tecrübeler 1şığında, araştırmanın amacı doğrultusunda öğretmen adaylarının paralellik inşalarını nasıl gerçekleştirdiklerini incelemek için her bir öğretmen adayına şu açıklamanın yer aldığg boş kâğıtlar verilmiştir: "Pergel ve birimsiz cetvelinizi kullanarak paralel doğrular (doğru parçaları) inşa ediniz. Inşadaki her bir aşamayı detaylı bir şekilde açıklayınız. Çizdiğiniz doğruların birbirine paralel olduğundan nasıl emin olduğunuzu gerekçeler sunarak açılayınız." Katılımciların her biri kendilerine ait olan pergel ve birimsiz cetveli kullanarak ve bireysel olarak paralellik inşalarını gerçekleştirmiştir. İnşa sürecinde, araştırmacı bireysel düşüncelere net olarak erişmek istediği için sınıf içi etkileşimin olmaması adına 68 kişilik sınıfı üçe bölerek verileri toplamıştır. Öğretmen adaylarına inşalarını gerçekleştirmeleri için süre kısıtlaması getirilmemiştir. Geometrik inşa sürecini ve açıklamalarını tamamlayan öğretmen adayları dokümanlarını teslim ederek sınıftan ayrılmıştır. Araştırmacı, bir haftalık sürede tüm katılımcıların yazılı cevaplarını analiz ederek paralellik inşalarının uygun veya uygun değil biçimde bir ön gruplama tabii tutmuştur. Yaptıkları geometrik inşalarda paralelliğin garanti olarak elde edildiği cevaplar uygun olarak kodlanırken, paralelliğin her zaman garanti olmadığ 1 ve hata içeren inşalar uygun değil biçiminde kodlanmıştır. Uygun inşalar ise cevap türlerindeki farklılıklara göre gruplanmıştır. Doğru ve yeterli cevaplar içinde farklı stratejileri kullanarak inşa yapanlar seçilmiştir ve sınıf tartışmasında ele alınmıştır. Hatalı veya eksik inşalar da benzer şekilde farklılıklarına göre gruplara ayrılmıştır.

Seçilen geometrik inşalar sınıf tartışmasında GeoGebra programında öğretmen adayı tarafından aynı şekilde yeniden inşa edilerek sınıf̧̧a inşanın doğruluğu ve nasıl gerekçelendirileceği üzerinde tartışmalar yapılmıştır. Öğretmen adaylarından cevabı ele alınan kişinin ilk önce pergel-cetvel inşası elektronik tahtada yansitılmıştır. Ardından öğretmen adayı, GeoGebra'da inşasını gerçekleştirerek doğrulamaya çalışmış ve ne yapmaya çalıştığını arkadaşlarıyla paylaşmıştır. Sınıf tartışmasında, öğretmen adayları birbirine istedikleri zaman sorular yöneltebilmişlerdir. $\mathrm{Bu}$ noktada, araştırmacı sınıf tartışmalarında rehberlik edici bir rol üstlenmiştir. Araştırmacı, katılımcılara söz verme, farklı düşünceleri ortaya çıkarma ve düşünceleri derinleştirmek için sonda sorularla devreye girmiştir. Ek olarak, GeoGebra'da yaşanan bir aksaklık veya inşada yaşanan büyük bir zorluk olursa katılımcılara yardımda bulunmuştur. Sınıf tartışmaları, iki grup 
halinde olan 68 kişiyle her iki gruba da üçer ders saati (bir ders saati 50 dakika) kadar süre ayrılarak gerçekleştirilmiştir. Sınıf tartışmaları sonunda öğretmen adaylarından ilk yaptıkları inşaları düşünerek, GeoGebra yazılımının kullanıldığı sınıf tartışmalarında geometri inşalarla ilgili neleri nasıl fark ettiklerine yönelik detaylı bir yansıtıcı düşünme raporu yazmaları istenmiştir.

\subsection{Verilerin Analizi}

Öğretmen adaylarının yazılı cevapları, sınıf tartışmaları ve yansıtıcı düşünme raporları araştırma sorularına göre içerik analizi yöntemi kullanılarak analiz edilmiştir. İçerik analizi, nitel veri analiz türleri arasında yazılı ve görsel veri yoğunluğunun fazla olduğu durumlarda kullanılan yöntemlerden biridir (Silverman, 2001). Bu yöntem doğrultusunda, tümdengelimci bir yaklaşımla veriler incelenerek ilgili konuda belli olası kategoriler oluşturulmuştur. Ardından, incelenen veri setinde, bu kategoriler içine giren kelime, cümle ve resimler kodlanarak kategoriler altına alınmıştır. Bu anlamda, öncelikle yapılan pergel-cetvel inşaları ve sunulan yazılı açıklamalar öğretmen adaylarına numaralar (ÖA1...-ÖA68) verilerek elektronik ortama aktarılmıştır. Daha sonra öğretmen adaylarının yaptıkları geometrik inşalar öncelikle paralellik oluşumu bakımından uygunluğuna göre incelenmiştir. Bir inşanın uygun olduğuna şu şekilde karar verilmiştir: Geometrik inşa, belirtilen adımlara göre çizildiğinde paralel doğrular elde ediliyor mu? Aynı inşa, GeoGebra'da da doğrulanıyor mu? Öğretmen adaylarının yaptıkları paralellik inşaları incelendiğinde, bazılarının dik doğruların inşası ile bazılarının ise eşkenar üçgenler inşa ederek veya daha farklı yollar kullanarak paralellik inşası yapmaya çalıştıkları fark edilmiştir. $\mathrm{Bu}$ yüzden, uygun geometrik inşalar belirlendikten sonra kullanılan yöntemlerdeki farklılıklara göre gruplama yapılmıştır. Bu sayede, öğretmen adaylarının paralellik inşası için hangi yolları ne sıklıkta tercih ettikleriyle ilgili detaylı bilgi edinilmiştir. Uygun geometrik inşalar, onların inşalarını gerekçelendirildiği anlamına gelmediği için inşalarda sunulan yazılı gerekçeler de analiz edilmiştir. Öğretmen adaylarının inşalarında gerekçe olanlar ve olmayanlar için frekans analizi yapılmıştır. Gerekçesiz inşa olarak kodlanan inşalarda öğretmen adayları ya sadece inşayı yapmış ya da inşa ile birlikte inşa aşamalarını gerekçe sunmadan yazmışlar veya hiç cevap vermemiş̧lerdir. Yapılan kodlama sonucunda oluşan kategorilerin her biri için açıklayıcı örnekler ve inşalara yer verilerek veriler detaylı şekilde bulgular kısmında doğrudan alıntılarla yorumlanarak sunulmuşstur.

Öğretmen adaylarının yaptıkları uygun olmayan geometrik inşalar ise öncelikle araştırmacı tarafından belli açıklayıcı notlar alınarak tabloya aktarılmıştır. Bu notlardan uygun olmayan paralellik inşalarında bazı öğretmen adaylarının sadece cetvel kullandıkları, bazılarının ise hem cetvel hem de pergel kullandıkları görülmüştür. Sadece cetvel kullanılarak yapılan paralellik örnekleri birer inşa olarak değerlendirilemeyeceği için uygun olmayan inşalarda pergel-cetvel kullanımına göre bir gruplama yapmak mantıklı bulunmuştur. Ek olarak, öğretmen adaylarının yaptıkları uygun olmayan inşalarda da belli paralellik özelliklerinden yola çıtıkları fark edilmiştir (ör., Paralel doğrular arasındaki uzaklık her zaman eşittir.). Bu nedenle, uygun olmayan inşalarda hangi özelliklerden yola çıkıldığı içerik analizine göre incelenerek gruplanmıştır. $\mathrm{Bu}$ 
gruplama sayesinde inşalardaki hataların geometrik anlamda nelerden kaynakladığı daha kolay görülebilmiştir. Öğretmen adaylarının GeoGebra yazılımı kullanılarak yapılan sınıf tartışmasında geometrik inşalarla ilgili neler fark ettiklerini gruplamak için sınıf tartışma verileri ve öğretmen adaylarının tartışma sonrasında yazdıkları yansıtıcı düşünme raporları incelenmiştir. Verilerden öğretmen adaylarının fark ettikleri noktalar ile ilgili dört kod çıkarılmıştır: (i) alternatif inşa yöntemlerini fark etme, (ii) inşalarda sağlam dayanaklar sunmanın gerekliliğini fark etme, (iii) hatalı varsayımların inşadaki etkisini fark etme ve (iv) GeoGebra yazılımı ile pergel-cetvelin geometrik inşa ve ispatlamadaki rolünü fark etme olarak isimlendirilmiştir. Araştırmada güvenirliğin sağlanması için verilerin \%25'i (17 öğretmen adayının geometrik inşaları) başka bir matematik eğitimcisi tarafindan doğruluğu, kullanılan stratejiler ve sunulan gerekçeler bakımından analiz edilmiştir. İki kodlayıcı tarafından ulaşılan sonuçlar Miles ve Huberman'ın (1994) uyum yüzdesi formülü kullanılarak hesaplanmıştır. Yapılan kodlamalar arasında \%89 uyum elde edilmiştir. Kodlayıcılar arası uyum yüzdesi \%70'in üzerinde olduğundan kabul edilebilir bir güvenirlik değeri elde edilmiştir. Fakat ortak kanaate varılmayan noktaların her biri kodlayıcılar arasında tartışılarak nihai bir karara varılmıştır. Ek olarak, araştırma yazarı tarafından veriler üç aylık süre zarfında ikinci kez kodlanarak kararlılık yöntemi ile çalışmanın güvenirliğine katkı sunulmuştur (Weber, 1985).

\section{Bulgular}

Araştırma bulguları dört temel başlık altında sunulmuştur. İlk olarak, öğretmen adaylarının yaptıkları paralellik inşaları ile ilgili genel bilgilere yer verilmiştir. Sonrasında ise uygun olan ve uygun olmayan geometrik inşa türleri ele alınmıştır. Son olarak, GeoGebra kullanılan sınıf tartışmalarında geometrik inşalarla ilgili nelerin fark edildiği sunulmuştur.

\subsection{Paralellik İnşalarının Genel Özellikleri}

Öğretmen adaylarının yaptıkları paralellik inşalarının genel özellikleri Tablo 1'de sunulmuştur. Tablo 1'e göre, öğretmen adaylarının sadece \%38'i pergel ve cetvel ile paralelliği uygun biçimde gerçekleştirmiştir. Öğretmen adaylarının \%37'si yanlış varsayımlara dayalı pergel-cetvel inşaları gerçekleştirirken $\% 15$ 'i ise pergel ve cetveli birlikte kullanmak yerine sadece cetvelle göz kararı bir paralellik sağlamaya çalışmıştır. Tablo 1'deki gerekçe sunma bilgileri incelendiğinde öğretmen adaylarının \%62'sinin yaptıkları inşalarda paralelliği nasıl elde ettiklerine dair gerekçeler sunmaya çalıştığı görülmektedir. $\mathrm{Bu}$ tablo, öğretmen adaylarının paralel inşalarını ne derece uygun yapabildiklerini ve gerekçe sunup sunamadıklarını göstermektedir. Öğretmen adaylarının paralel inşalarında hangi yöntemleri tercih ettikleri, sundukları gerekçelerin içerikleri ve uygun olmayan geometrik inşalardaki yaklaşımların neler olduğu konularındaki detaylar ayrı başlıklar altında ele alınmıştır. 
Tablo 1. Öğretmen adaylarının yaptıkları paralellik inşaların genel özellikleri

\begin{tabular}{|c|c|c|c|c|c|c|}
\hline \multirow{3}{*}{$\begin{array}{l}\text { Geometrik inşalar } \\
\text { Uygun paralellik insaları }\end{array}$} & \multicolumn{6}{|c|}{ S1klı (f) (\%) } \\
\hline & \multicolumn{2}{|c|}{ Gerekçeli } & \multicolumn{2}{|c|}{ Gerekçesiz } & \multicolumn{2}{|c|}{ Toplam } \\
\hline & 19 & (28) & 7 & (10) & & (38) \\
\hline \multicolumn{7}{|l|}{ Uygun olmayan paralellik inşaları } \\
\hline - Yanlış varsayımlara dayalı pergel-cetvel inşaları & 16 & (24) & 9 & (13) & 25 & (37) \\
\hline - Yanlış varsayımlara dayalı cetvel çizimleri & 7 & (10) & 3 & (5) & 10 & (15) \\
\hline - Alakasız geometrik inşalar & 0 & 0 & 5 & (7) & 5 & (7) \\
\hline Cevapsız & 0 & 0 & 2 & (3) & 2 & (3) \\
\hline Toplam & 42 & (62) & 26 & (38) & 68 & $(100)$ \\
\hline
\end{tabular}

\section{2. Öğretmen Adaylarının Yaptığı Uygun Paralellik İnşaları ve Yöntemleri}

Öğretmen adaylarının uygun paralel doğru inşaları incelendiğinde dört farklı yolla paralellik inşalarını elde ettikleri görülmektedir (Bkz. Tablo 2). Bu yöntemler arasında öğretmen adaylarının sıklıkla tercih ettikleri yöntemler eşkenar üçgen ve dik doğrular yöntemleri olurken, açı kopyalama ve eşkenar dörtgen yöntemleri daha az tercih edilen paralellik inşa yöntemleri olmuştur. Kullanılan inşa yöntemleri, öğretmen adaylarının paralellik inşası için eşkenar üçgen, açı taşıma, diklik gibi temel geometrik inşalardan faydalandıklarını göstermektedir. Ayrıca Tablo 2 öğretmen adaylarının birçoğunun inşalarında paralellikten nasıl emin olduklarına dair gerekçe sunduklarını göstermektedir.

Tablo 2. Uygun paralellik inșalarında kullanılan yöntemler

\begin{tabular}{|c|c|c|c|}
\hline \multirow[t]{2}{*}{ İnşa yöntemleri } & \multicolumn{2}{|c|}{ Siklık (f) } & \multirow[t]{2}{*}{ Gerekçe örneği } \\
\hline & Gerekçeli & Gerekçesiz & \\
\hline Dik doğrular yöntemi & 9 & 0 & $\begin{array}{l}\text { Aynı doğruya dik olan iki doğru birbirine } \\
\text { paraleldir. }\end{array}$ \\
\hline Eşkenar üçgen yöntemi & 6 & 7 & $\begin{array}{l}\text { Tabanları aynı doğru üzerinde bulunan iki eş } \\
\text { eşkenar üçgenin köşe noktalarının tabanların } \\
\text { bulunduğu doğru parçasına olan uzaklıkları } \\
\text { eşittir. Bu nedenle, üçenlerin tepe noktalarının } \\
\text { birleşimiyle oluşan doğru parçası üçgenlerin } \\
\text { tabanın bulunduğu doğru parçasıa paraleldir. }\end{array}$ \\
\hline Açı kopyalama yöntemi & 2 & 0 & Yöndeş açılar eşse doğru parçaları paralel olur. \\
\hline Eşkenar dörtgen yöntemi & 2 & 0 & $\begin{array}{l}\text { Oluşan dörtgenin tüm kenarları, yarıçap } \\
\text { uzunluğuna eşit olduğundan birbirine eşittir. } \\
\text { Eşkenar dörtgende ise karşılıklı kenarlar birbirine } \\
\text { paralel olur. }\end{array}$ \\
\hline
\end{tabular}

Toplam sıklık (f)

19

7

Dik doğrular yöntemi: Paralel doğruların inşasında 9 öğretmen adayı dik doğrular yöntemini kullanmıştır. Yedi öğretmen adayı, bir doğruya üzerindeki noktalardan iki dik doğru inşa ederken, iki öğretmen adayı bir doğruya dışındaki iki farklı noktadan diklik inşa etmiştir. Öğretmen adaylarının bazılarının geometrik inşaları ve yaptıkları açıklamalar Şekil 1'de sunulmuştur. Örneğin, ÖA9 bir doğrunun üzerindeki noktalardan çizilen diklik inşasını göstermektedir. ÖA9 öncelikle [AB] doğru parçasını çizmiş ve ardından bu doğru parçasının orta dikmesini inşa etmiştir. Ardından, orta dikme doğrusunu uzatarak [CD]'nin orta dikmesini de inşa etmiştir. Bu sayede, öğretmen adayı 
$[\mathrm{AB}] \perp \mathrm{d}$ ve $\left[\mathrm{A}^{\prime} \mathrm{B}\right.$ '] $\perp[\mathrm{CD}]$ sonucuna varmıştır. Yaptığ doğrusu üzerindedir. Ayrıca $[A B] \perp d$ ve [A'B'] $\perp d$. Aynı doğruya dik olan iki doğru birbirine paralel olacağından $[A B] / /[A$ ' $B$ '] olur." biçiminde yazılı bir gerekçe sunmuştur. Aynı yöntemle paralel doğru inşası yapan öğretmen adayları da benzer gerekçeler sunarak yaptıkları çizimden nasıl emin olduklarını açıklamıştır. Diğer taraftan, iki öğretmen adayı doğrunun dışındaki bir noktadan indirilen dikmelerin paralel doğruların inşasında etkili ve kolay bir yol olduğunu belirtmiştir. Örneğin, ÖA8 M noktasından [AB]'ye pergel ve cetvelini kullanarak bir dikme inşa etmiştir. Yaptığ 1 geometrik inşada aynı şekilde $[A B]$ üzerinde olmayan başka bir noktadan bir dikme inşa edildiği takdirde elde edilen dikmelerin daha önce bahsi geçen gerekçelere benzer şekilde birbirine paralel olacağını belirtmiştir.

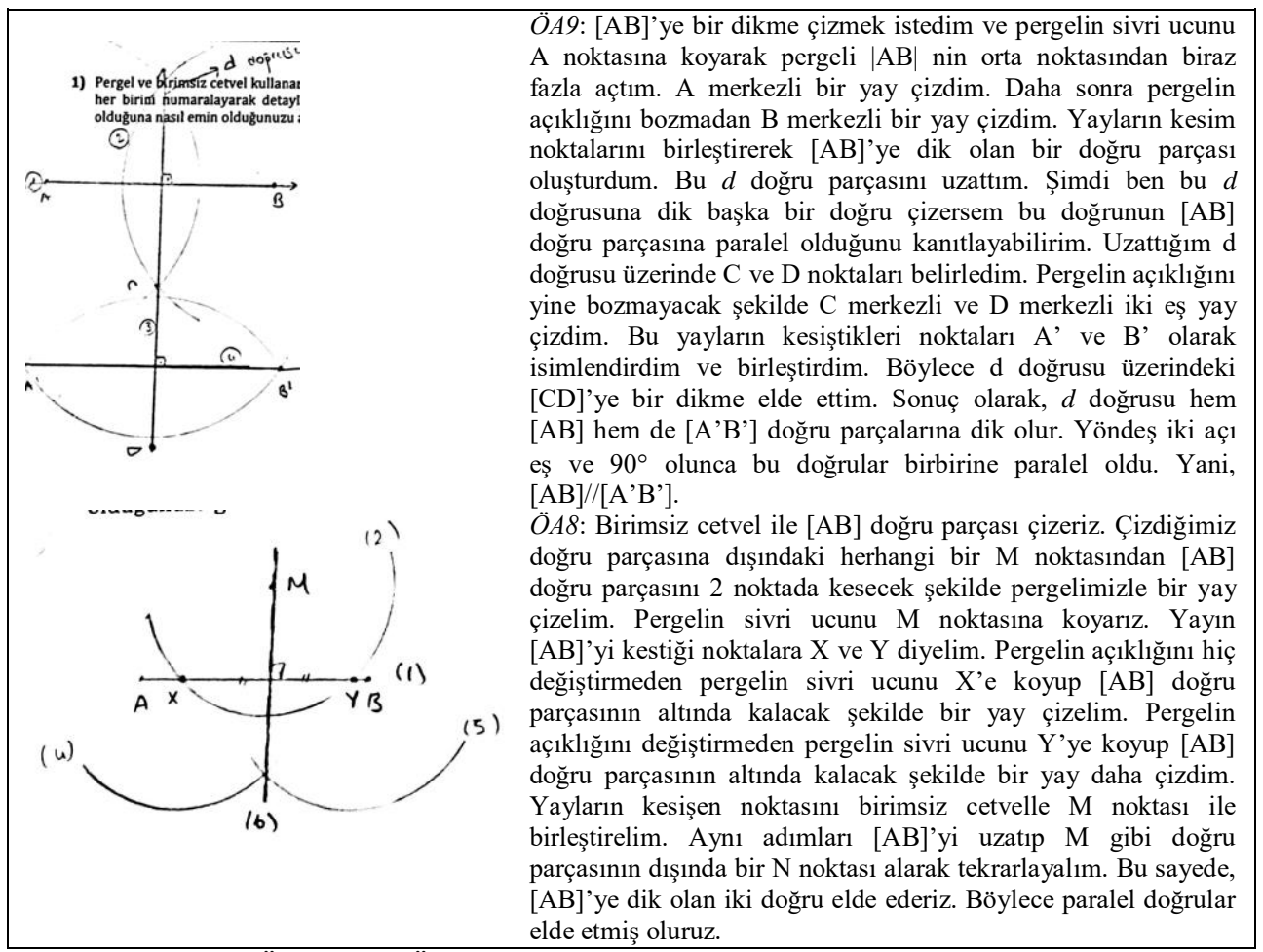

Şekil 1. ÖA8'in ve ÖA9'un dik doğrular yöntemiyle paralellik inşaları

Açı kopyalama yöntemi: Sadece iki öğretmen adayı açı kopyalama yöntemini kullanarak paralel doğruların inşasını gerçekleştirebilmiştir. $\mathrm{Bu}$ yöntemde öğretmen adayları diklikten ziyade birbirine eş ve ışın kollarından biri ortak olan iki açı inşa etmeye çalışmıştır. Pergel açıklığını ayarlayarak ilk elde ettikleri açıya eş nasıl bir açı elde edebileceklerini bulmuşlardır. Öğretmen adaylarından birinin yaptığı geometrik inşa ve açıklamalar Tablo 3’te yer almaktadır. ÖA26 köşe noktası O olan açıyı $l$ doğrusu boyunca 
köşe noktası $\mathrm{O}_{1}$ olacak şekilde kopyalamıştır. İnşada pergel ve cetvelle yapılması gereken tüm adımları tamamlayıp açıkladıktan sonra, ÖA26 $\left[\mathrm{O}_{1} \mathrm{~B}_{1}\right]$ doğru parçasını çizmiş ve $d$ doğrusu ile çizdiği $\left[\mathrm{O}_{1} \mathrm{~B}_{1}\right]$ 'in birbirine paralel olduğunu iddia etmiştir. ÖA26 bu sonuca nasıl vardığını açıklamak için şu gerekçeleri sunmuştur: "Açının aynısını tekrar ortak doğru üzerinde oluşturduğum için $\angle A O B$ ile $\angle A_{l} O_{1} B_{1}$ eştir. Ĕger iki yöndeş açı eşse bu doğrular birbirine paralel olur. Pergel kayınca biraz yamuk oldu ama tekrar çizmedim." Açıklama ve inşadan görüleceği üzere, ÖA26 kullandığı açı özellikleri ile paralellik kavramını ilişkilendirerek geometrik inşasını tamamlamıştır.

Eşkenar dörtgen yöntemi: Paralel doğruların inşasında eşkenar dörtgen yönteminin açı kopyalama ve üçgen öteleme gibi yöntemlere göre pergel kullanımı açısından çok daha kolay olduğunu söyleyebiliriz. Buna rağmen, Tablo 3 'te de bir örneği sunulduğu gibi sadece iki öğretmen adayı eşkenar dörtgen yöntemi ile paralel doğruları kolaylıkla inşa etmiştir. Örneğin, ÖA34 cetvelle bir [AB] doğru parçası inşa ettikten sonra bu doğru parçası uzunluğu kadar pergelini açmıştır. A ve B noktalarına pergelin sivri ucunu koyarak yarıçapı $[\mathrm{AB}]$ uzunluğunda olan iki çember inşa etmiştir. Öğretmen adayı, çemberlerin kesişim noktaları ve merkez noktalarını cetvelle birleştirerek ADBC eşkenar dörtgenini elde etmiştir. ÖA34 yazılı olarak şu gerekçelere yer vermiştir: "Ben pergelin açıklı̆̆ını değiştirmediğim için dörtgenin tüm kenar uzunlukları AB kadar oldu. O nedenle eşkenar dörtgen elde ettim. Eşkenar dörtgenin karşıllklı kenarları hem eşit hem de paralel olur. $|A C| / / B D \mid$ ve $|A D| / /|B C|$. Böylece birbirine paralel iki doğru çizmiş oluruz." Öğretmen adayının sunduğu gerekçelerde paralelkenar özelliklerinden faydalanarak paralel doğrular inşasını ortaya çıkardığı rahatlıkla görülmektedir.

Tablo 3. Açı kopyalama ve eșkenar dörtgen yöntemleriyle paralellik inşa örnekleri

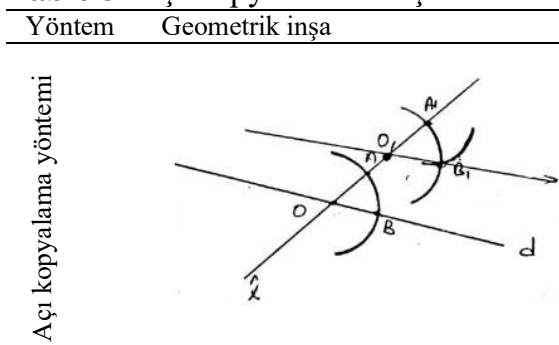

Açıklamalar

$\ddot{O} A 26$ : $d$ doğrusu çizdim. Rasgele bir $l$ doğrusu çizip $\angle \mathrm{AOB}$ oluşturdum. Paralel doğruların eğimleri aynıdır bu yüzden açı taşıma yöntemini kullanmaya karar verdim. Pergelin açıklı̆̆ını değiştirmeden bir açı daha oluşturacağım. Merkezi $\mathrm{O}_{1}$ kestiği yer $\mathrm{A}_{1}$ olur. $\mathrm{A}_{1}{ }^{\prime} \mathrm{e}$ pergelimin açıklığını $\mathrm{AB}$ arası kadar ayarlayarak koydum ve açının diğer ışından oluşan kolunu $B_{1}$ noktasına yerleştirdim. Sonra $\mathrm{O}_{1}$ ve $\mathrm{B}_{1}$ noktalarııı birleştirdim. İki yöndeş açı eş olunca doğrular birbirine paralel oldu. Pergelden elim kaydığı için görüntü biraz kötü oldu.

ÖA34: $[\mathrm{AB}]$ doğru parçası çizelim. A noktası merkez

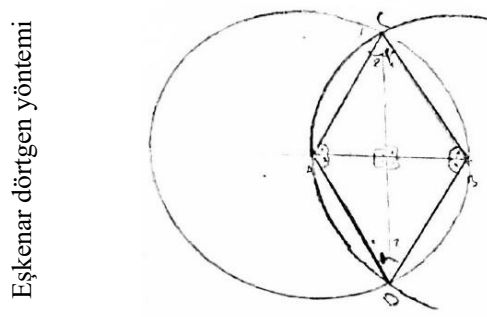
olacak şekilde ve $A B$ yarıçap olacak şekilde bir yay çizelim. Pergel açıklığını bozmadan aynı işlemi B noktası için uygulayalım. Yayların kesim noktaları C ve D ile A ve B noktalarını cetvelle birleştirelim. Ben pergelin açıklığını değiştirmediğim için dörtgenin tüm kenar uzunlukları $\mathrm{AB}$ kadar oldu. $\mathrm{O}$ nedenle eşkenar dörtgen elde ettim. Eşkenar dörtgenin karşılıklı kenarları hem eşit hem de paralel olur. $|\mathrm{AC}| /|\mathrm{BD}|$ ve $|\mathrm{AD}| /|\mathrm{BC}|$. Böylece birbirine paralel iki doğru çizmiş oluruz. 
Eşkenar üçgen yöntemi: Bu yöntemde öğretmen adayları üç veya daha fazla sayıda aynı yarıçap uzunluğuna sahip çember ya da yay inşa ederek onların kesişim noktalarına odaklanmıştır. Elde ettikleri noktaları cetvelle birleştirdiklerinde iki eş eşkenar üçgene ulaşmışlardır. Bazıları tabanları aynı doğru parçası üzerinde olan eş eşkenar üçgenlerin tepe noktalarını birleştirerek üçgen tabanına paralel doğru parçası inşa ederken, bazıları ise bu üçgenlerin tepe noktasından dikmeler inşa ederek iki paralel doğru elde etmeye çalışmıştır. Toplamda 13 öğretmen adayı eşkenar dörtgen yöntemini kullanarak paralel doğrular inşasını uygun biçimde yapabilmiştir. Fakat bunlardan sadece 6'sı yaptıkları geometrik inşalar için gerekçeler sunabilmiştir. Gerekçe sunan (ÖA37) ve sunamayan (ÖA11) bazı öğretmen adaylarının yaptıkları paralel doğru inşaları Tablo 4'te gösterilmiştir.

Tablo 4. Öğretmen adaylarının eşkenar üçgen yöntemiyle paralellik inşaları

Geometrik inşalar

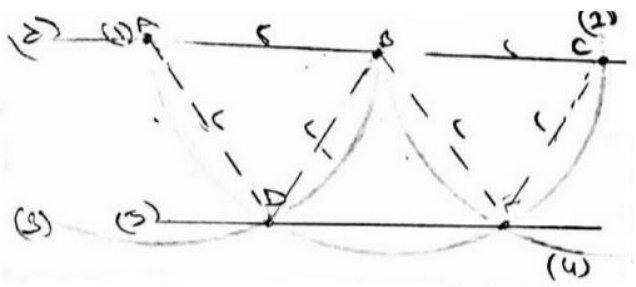

ÖA37: İlk olarak, cetvelle $d$ doğrusunu çizdim. Pergeli açarak A noktasına koydum ve bir yay çizdim. Yay ile $d$ doğrusunun kesişim noktasına B dedim. Pergel açıklığını değiştirmeden, B noktasından bir çember daha çizdim. Bu çember ile d doğru A ve $\mathrm{C}$ noktasında kesişti. Benzer şekilde, yine pergel açıklığını değiştirmeden C noktasından bir çember daha çizdim. Çemberleri $d$ doğrusu altında kesiştikleri noktaları D ve F olarak isimlendirdim. Cetvelle D ve F noktalarını birleştirdim. Pergel açıklığı değişmediğinden tüm çemberler aynı yarıçapa sahip oldu. Bu yüzden, ABD ve BCF eş eşkenar üçgenler oldu. Tabanları aynı doğru üzerinde olduğu için de aynı yüksekliğe sahip oldular. Sonuçta, $[\mathrm{DF}]$ ve [AC] arasındaki uzaklık her zaman eşit oldu ve $[\mathrm{AC}] / /[\mathrm{DF}]$ oldu.

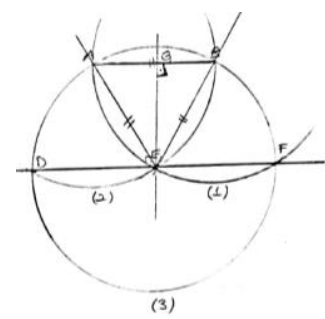

ÖA11: (I) [AB] çizilir. Pergel [AB] kadar açılır. (II) $\mathrm{B}$ merkezli ve $[\mathrm{AB}]$ yarıçaplı bir yay (1) çizilir. (III) A merkezli ve [AB] yarıçaplı bir başka yay (2) daha çizilir. (IV) İki yayın kesim noktası merkez olacak şekilde [AB] yarıçaplı bir çember çizilir. (V) (2) ve (3) ün kesim noktasina D denir. (2) ve (1)'in kesim noktasina da E denir. (1) ve (3) kesim noktası da F olarak isimlendirilir. (VI) A-B-E noktaları cetvel ile birleştirilir ve AEB eşkenar üçgeni üretilir ve $[\mathrm{AB}] / /[\mathrm{DF}]$ olur. Paralelliği kontrol için cetvelle doğrular arası uzaklık ölçülebilir.

$\mathrm{Bu}$ yöntemi kullanan öğretmen adaylarının inşalarında belli ortak özelliklerin olduğu görülmüştür. Örneğin, öğretmen adaylarının hepsi inşa sürecine bir doğru parçası oluşturarak başlamıştır. Diğer bir ortak nokta ise öğretmen adaylarının pergel açıklığını hiç bozmadan üç çember veya yay üretmeleridir. Ek olarak, öğretmen adayları ürettikleri çemberlerin kesim noktalarına ve çember merkezlerine odaklanmışlardır. Bu noktaları cetvelle birleştirerek eşkenar üçgenler elde etmeye çalışmışlardır. Sonuçta ise ilk ürettikleri doğru parçasına paralel olacak başka bir doğru parçasını elde etmeyi amaçlamışlardır. Özellikle eşkenar üçgen yöntemi grubuna giren geometrik inşalarda yaptıkları paralel inşaları için gerekçe sunan öğretmen adayları, Tablo 4'teki ÖA37'nin açıklamalarında olduğu gibi gerekçelerinde eşkenar üçgen ve özelliklerinden faydalanmışlardır. Diğer taraftan, eşkenar üçgen yöntemini kullanan 7 öğretmen adayı 
doğru geometrik inşaları yaparak paralellik elde ettiğini belirtse de herhangi bir gerekçe sunamamıştır. Odaklandıkları tek nokta, pergel açıklığını değiştirmemeleri olmuştur. $\mathrm{Bu}$ öğretmen adaylarının bazıları şu şekilde açıklamalar yapmıştır. "Pergel açıklığını bozmadığım için paralel olduğunu düşünüyorum." Örneğin, Tablo 4'te inşası ve açıklamaları bulunan ÖA11 bir eşkenar üçgen çizmesine rağmen bu üçgeni inşasını gerekçelendirmede kullanmamıştır. Ayrıca ÖA11, inşası için bir gerekçe sunmaktan ziyade doğru parçaları arasındaki uzaklığın sabit kaldığını görmek için birimli bir cetvelle ölçüm yapılmasını önermiştir fakat paralel olmayı nasıl garantilediğini açıklayamamıştır.

\subsection{Paralel Doğrular İçin Uygun Olmayan Geometrik İnşalar}

Daha önce Tablo 1'de sunulan bilgiler, öğretmen adaylarının \%52'sinin $(\mathrm{n}=35)$ paralel doğrular bakımından uygun olmayan geometrik inşalar ürettiklerini ortaya çıkarmıştı. Hatalı geometrik inşalar yapan öğretmen adaylarının yola çıktıkları paralellik özellikleri ve pergel-cetvel kullanımlarının detayı Tablo 5'te sunulmuştur. Öğretmen adaylarının pergel-cetvel kullanımları incelendiğinde hatalı inşa yapan 35 kişinin 10'unun sadece cetveli kullandığını göstermiştir. Sadece cetvel kullanan öğretmen adayları aslında geometrik bir inşadan ziyade bir çizim yapmıştır.

Tablo 5. Paralel doğrular için uygun olmayan geometrik inşaların özellikleri

İnşa sürecinde yola çıkılan paralellik özellikleri

Aynı doğruya dik olan iki doğru birbirine paraleldir

Yöndeş açıların ölçüsü eşit ise doğrular paraleldir Pergel-cetvel kullanım frekansları

Sadece cetvel Cetvel ve pergel

kullananlar kullananlar

Paralel doğrular arasındaki uzaklık her zaman eşittir

$\begin{array}{ll}0 & 9 \\ 8 & 0\end{array}$

Bir doğruya dışındaki noktadan yalnız bir paralel doğru

8

0

çizilir

Paralelkenarın karşlıklı kenarları birbirine paraleldir

Toplam (f)

2

9

$0 \quad 5$

0

10

25

“Aynı doğruya dik olan iki doğru birbirine paraleldir" üzerine kurulan uygun olmayan inşalar: Uygun olmayan paralellik inşası yapanlar arasında 9 kişi "aynı doğruya dik olan iki doğru birbirine paraleldir" düşüncesi üzerinden geometrik inşalarını gerçekleştirmiştir. Bu kişilerin tümü yaptıkları geometrik inşalarda hem cetvel hem de pergeli kullanmaya çalışmışlardır. Paralellikle ilgili temel alınan düşünce doğru olsa da geometrik inşalarında birçok problemli noktanın olduğu tespit edilmiştir. Öğretmen adaylarının yaptıkları yanlış inşalarda nasıl yol izledikleri ve inşa sürecinin hangi aşamasında hata yaptıkları yapılan inşa çeşitlenmesini de gösterme adına Şekil 2'de sunulmuştur.

Yapılan geometrik inşalar dikkatle incelendiğinde, ÖA1, ÖA4, ÖA55 ve ÖA24 ortak bir yol izlemiş̧tir. Bu öğretmen adaylarının yaptıkları inşalar, öğretmen adaylarında tek bir noktanın pergel ve cetvel ile bir doğru çizmede yeterli olduğu görüşünün var olduğunu göstermiştir. Fakat bir doğrunun çizilebilmesi için iki nokta olması gerekir. Örneğin, ÖA1 yaptığı inşa adımlarındaki açıklamalarında da net olarak şunu belirtmektedir: "Yarıçapları eş olan çemberleri kesiştirdim. Kesişim noktasından çizdiğim doğrular paralel olur. 
Çünkü çapa dik iki doğru elde ettim.” Öğretmen adayının dik doğruları kullanarak paralel inşa etmeye çalıştığı açıktır fakat tek bir noktayı referans alarak çember merkezlerinden geçen doğruların birbirine paralel olması böyle bir çizim yoluyla her zaman mümkün değildir. Diğer taraftan, ÖA4 ise çemberleri birbirine teğet olacak biçimde inşa etmeye çalıştığını ve teğetten çizdiği doğrunun çapa dik olacağını belirtmiştir. Ayrıca çemberin merkezinden geçen doğru ile çemberlerin birbirine teğet olduğunu iddia ettiği noktadan geçen doğruların da gerekçe sunmadan paralel olacağı sonucuna varmıştır. Diğer ilginç bir geometrik inşa da yine dik doğrular metodunu düşünerek ÖA55 tarafindan yapılmıştır. ÖA55 inşa için yazdığı adımlarda net bir şekilde bir doğrunun orta dikmesini bulma inşası gerçekleştirdiğini belirtmiştir. Çizdiği iki yayın kesim noktalarını birleştirerek [AB]'ye dik bir doğru parçası oluşturmuştur. Yayların kesim noktalarından birini seçerek cetvelle $\mathrm{d}_{2}$ doğrusunu çizmiş ve bu doğrunun $\left(\mathrm{d}_{1}\right)$ [AB]'ye paralel olacağını iddia etmiştir. Gerekçesinde ise "iki doğrunun üçüncü doğru ile kesiştikleri yerlerde açıları diktir. Bu şekilde dik olunca da $d_{1} / / d_{2}$ paralel olur." yazmıştır. Sonuç olarak, bu öğretmen adayı aynı doğruya dik olan iki doğru birbirine paraleldir düşüncesini ispat sunamadan benimsemiş ve yanlış kabuller üzerine her zaman doğru olmayacak bir inşa gerçekleştirmiştir.

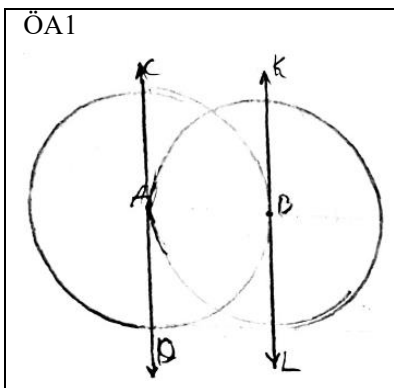

ÖA55
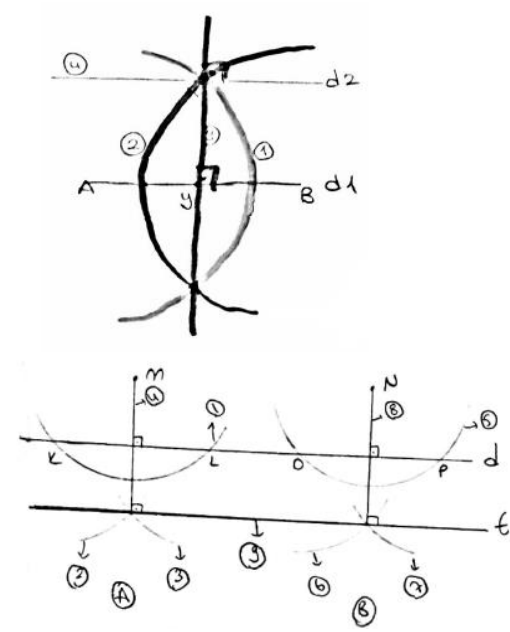

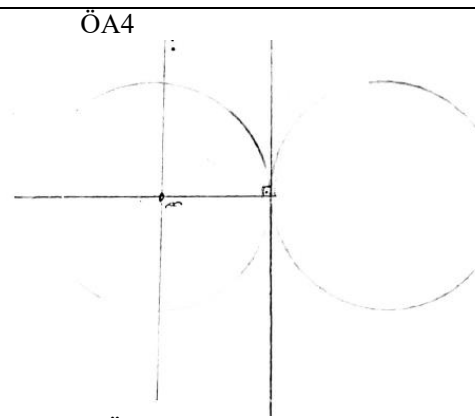

ÖA24

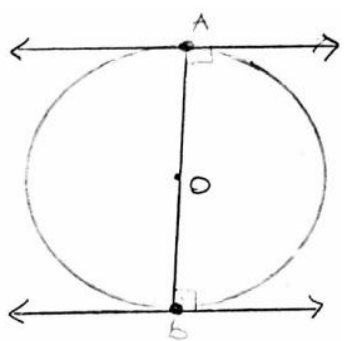

ÖA3: Pergel yardımıyla M merkezli d doğrusunu kesen bir yay çizilir. Kestiği noktalara $\mathrm{K}$ ve diyelim. Pergel açıklı̆̆ bozulmadan K merkezli bir yay çizilir. Açıklık bozulmadan L merkezli bir yay daha çizilir. Yayların kesim noktası ile M noktası birleştirilir. Aynı işlemler N noktası için de yapılır. t Sonra A ve B bölgelerindeki yayların kesim noktaları birleştirilir. Böylece d doğrusuna paralel bir t doğrusu elde edilir. Öklid postulatına göre tüm dik açılar eştir ve diklikten dolayı doğrular paraleldir.

Şekil 2. Öğretmen adaylarının diklik kullanarak yaptıkları hatalı inşalar 
ÖA24 de dik doğrulara odaklanarak paralellik elde etme düşüncesiyle A ve B noktalarında çembere teğet olan iki doğrunun birbirine paralel olduğunu iddia etmiştir. Fakat belirtilen teğet noktalarından sonsuz sayıda doğru çizilebilir ve bu çizilen doğrulardan sadece bir çifti birbirine paralel olabilir. Diğer önemli bir nokta ise pergelcetvel ile yapılan geometrik bir inşada teğet noktasının göz kararı belirlenmiş olmasıdır. Oysa pergel-cetvel ile yapılan inşalarda bu şekilde teğet noktası belirlemek mümkün değildir. Bu geometrik inşalar arasında ÖA3 dik doğrular metodu ile paralel doğru inşa etmeye oldukça yaklaşmıştır. Hatta son adımda yanlış bir yargıya varmasaydı paralel doğrulara erişmiş olabilirdi. Fakat öğretmen adayının cevabındaki en önemli eksiklik M ve $\mathrm{N}$ noktalarının aynı hizada olup olmadığını bilmeden inşa ettiği yaylarla paralel doğrular elde etmeye çalışmasıdır. Normalde, ÖA3 yaptığı inşada [KL] ve [DP]'nin orta dikmelerini elde edebilmiştir. $\mathrm{Bu}$ durumda, aslında bu orta dikmelerin birbirine paralel olduğunu iddia edebilirdi. Fakat öğretmen adayı, A ve B bölgeleri olarak isimlendirdiği yerdeki noktaları birleştirdiğinde $\mathrm{d}$ doğrusuna paralel bir t doğru inşa edebilmesinin $\mathrm{M}$ ve $\mathrm{N}$ aynı hizada olmadığı sürece bir garantisi olmadığının farkında değildir.

“Yöndeş açıların ölçüsü eşit ise doğrular paraleldir" üzerine kurulan uygun olmayan inşalar: Tablo 5 'te görüldüğü üzere, 8 öğretmen adayı yaptıkları paralel doğru inşalarında yöndeş açıların eş olma durumundan yola çıkmıştır. Fakat bu öğretmen adayları bir inşadan çok sadece bir çizim yapma eğilimi göstermişlerdir. Düz çizgiler elde edebilmek için sadece cetvel kullanmışlardır. $\mathrm{Bu}$ nedenle, sunulan cevaplar bir inşa özelliği dahi taşımamaktadır (Bkz. Şekil 3).

\begin{tabular}{|c|c|}
\hline $\int_{13(3)}^{d \rightarrow d_{4}(u)}$ & $\begin{array}{l}\text { ÖA67: } \mathrm{d}_{1} / / \mathrm{d}_{2} \text { ve } \mathrm{d}_{3} \text { doğrusu bu iki doğruyu } \mathrm{A} \text { ve } \mathrm{B} \text { gibi } \\
\text { noktalarda kessin. } \angle \mathrm{A}_{1} \cong \angle \mathrm{B}_{1} \text { (yöndeş aç1lardan) } \\
\text { İspat: Olmayana Ergi ile diyelim ki } \mathrm{d}_{1}, \mathrm{~d}_{2} \text { 'ye paralel olmasın. } \\
\text { Onun yerine } \mathrm{d} 4 \text { gibi bir doğruyu } \mathrm{d}_{2} \text { doğrusuna (farklı) paralel } \\
\text { alalım. Yöndeş açılar eş olduğundan } \angle \mathrm{A}_{2} \cong \angle \mathrm{B}_{1} \text {. Bu durumda, } \\
\angle \mathrm{A}_{1} \cong \angle \mathrm{A}_{2} \text {. Yani } \mathrm{d}_{1} \text { ve } \mathrm{d}_{4} \text { doğruları çakışı oldu. Hâlbuki biz } \\
\text { en başta doğruların farklı olduğunu söylemiştik. Yani bu } \\
\text { demektir ki kabulümüz yanlıştır. Yöndeş açllar eş olduğundan } \\
\mathrm{d}_{1} \text { ve } \mathrm{d}_{2} \text { doğruları paraleldir. }\end{array}$ \\
\hline
\end{tabular}

Şekil 3. ÖA67'nin olmayana ergi yöntemiyle paralellik ispatı

ÖA67 pergel ve cetvel kullanılarak yapılması gereken geometrik inşayı yapamadığını belirterek bu yöntemi kullandığını sınıf tartışmasında belirtmiştir. Öğretmen adayı, çizdiği $d_{1} / / d_{2}$ ve $d_{3}$ doğrusu bu iki doğruyu A ve B gibi noktalarda kessin dedikten sonra yöndeş açıların eş olma durumuna odaklanmıştır. $d_{1}$ 'in $d_{2}$ 'ye paralel olmadığını iddia ederek çelişki yaratmış ve paralelliği göstermeye çalışmıştır. Her ne kadar ispat olarak doğru bir yol izlense de öğretmen adayı pergel-cetvel kullanmadığı ve bu yönde gerekçeler sunmadığ için istenen geometrik inşaya erişememiştir.

Esasında yöndeş açıların eşliğini kullanmak isteyen öğretmen adayları paralel doğruların inşası için açı kopyalama metodunu tercih edebilirdi. Bu yönde, bir öğretmen adayı bu metodun işe yarayabileceğini kestirmiş fakat istenen geometrik inşayı 
gerçekleştirememiştir. $\mathrm{Bu}$ anlamda, ÖA2 açının taşınması gerektiğini yazılı olarak belirtmesine rağmen sadece cetvelle Şekil 4 'teki gibi bir çizim yapmıştır.

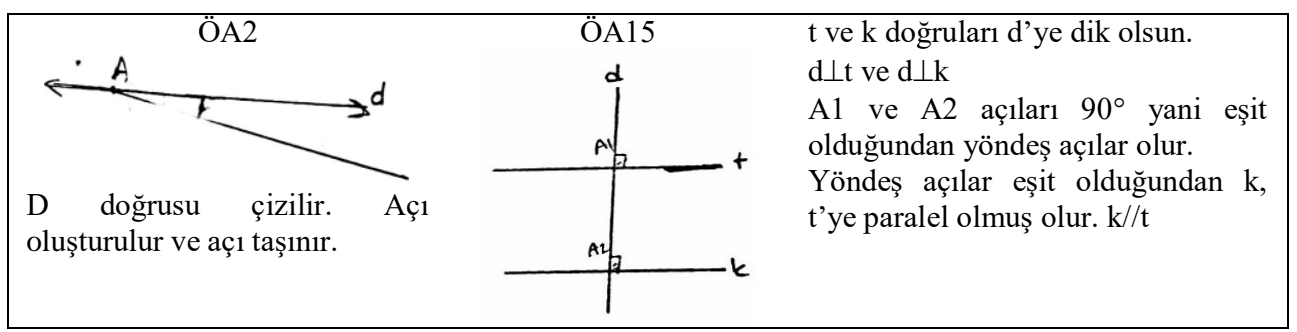

Şekil 4. Yöndeş açılara dayanarak yapılan uygun olmayan paralellik inşaları

Diğer taraftan, ÖA15 daha ilk baştan doğruların $d$ doğrusuna dik olduğunu varsayarak paralelliği gösterme yoluna girmiştir. Sonuç olarak, yöndeş açıların ölçüsünün eşit olması fikri paralel doğruların inşalarını oluşturmada ve gerekçelendirmede önemli ve etkili bir yol olmasına rağmen öğretmen adayları tarafından yanlış varsayımlara dayanarak eksik veya hatalı biçimde kullanılmıştır.

\section{"Paralel doğrular arasındaki uzaklık her zaman eşittir" üzerine kurulan uygun} olmayan inşalar: 11 öğretmen adayı, paralel doğru inşalarında paralel doğrular arasındaki uzaklığın eşitliğine odaklanmışlardır. Fakat yaptıkları geometrik inşaları yanlış varsayımlara dayandırmışlardır. Bu öğretmen adaylarından ikisi sadece cetvelle çizim yaparken geriye kalan 9 kişi hem pergel hem de cetveli kullanmaya çalışmıştır. Sadece cetvel kullanarak paralellik inşa ettiğini düşünen iki öğretmen adayının çizimleri ve açıklamaları Şekil 5 'te sunulmuştur.

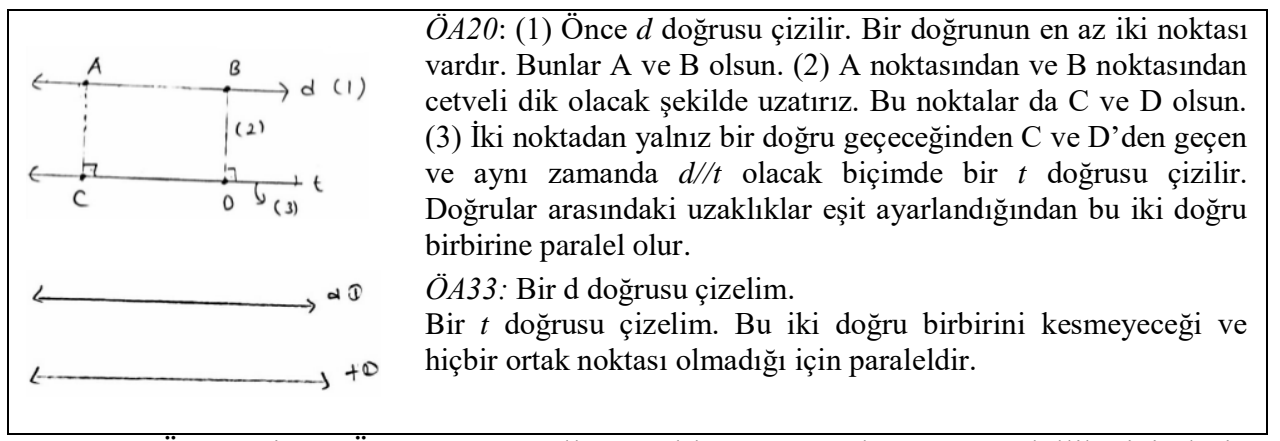

Şekil 5. ÖA20'nin ve ÖA33'ün cetvelle yaptıkları uygun olmayan paralellik çizimleri

Örneğin, ÖA20 A ve B noktalarından pergel olmaksızın cetvelle dik doğrular çizdiğini iddia etmiştir. Oluşturduğu $d$ ve $t$ doğrularının aralarındaki uzaklığın eşit uzunlukta olduğunu da belirtmiştir. Fakat bu varsayımlara dayanarak yapılan paralel doğrular bir inşadan çok çizim ürünü olmuştur. Bu nedenle, öğretmen adayı her zaman doğru olacak bir sonuç elde edemezken geometrik inşanın altında yatan gerçekleri ve gerekçeleri sorgulayamamıştır. Benzer şekilde, ÖA33 de sadece cetvelle çizdiği iki doğrunun 
birbirine paralel olacağını iddia etmiştir. Fakat bu durumun garantisi yoktur. Sonuç olarak, görülüyor ki bazı öğretmen adayları paralel doğrulara has özellikler üzerinden giderek zihinlerinde belirledikleri ve kabul ettikleri varsayımlara dayanıp yaptıkları çizimlere paralel doğrular inşası muamelesi yapmışlardır.

Paralel doğrular arasındaki uzaklık her zaman aynıdır düşüncesine yoğunlaşan ve cetvele ek olarak pergeli de kullanarak uygun olmayan geometrik inşa yapan öğretmen adayları ise pergeli iki doğru arasındaki uzaklığı sabitlemek amacıyla kullanmışlardır. $\mathrm{Bu}$ durumun temel nedeni olarak cetvelin birimsiz olmasından dolayı ölçüm yapamamalarını gerekçe göstermişlerdir. Örneğin, ÖA56 pergel açıklığını bozmadan pergelin sivri ucunu sırasıyla A ve B noktalarına yerleştirip C ve D noktalarını elde ettiğini belirtmiştir (Bkz. Şekil 6-a). C ve D noktalarının birleşimi ile oluşan doğrunun ise [AB]'ye paralel olacağını iddia etmiştir. Fakat pergel açıklığ 1 her ne kadar bozulmasa da pergelle ölçüm yapma fikri $[\mathrm{AC}]$ ile $[\mathrm{BD}]$ doğru parçalarının aynı uzunlukta olmasını garanti etmez. Bu uzunlukların aynı olması pergelle çizilen eş yayların kesim noktaları aracılığıyla sağlanabilirdi. Fakat öğretmen adayı baştan paralel doğrular arası uzaklık hep aynı olmalıdır düşüncesiyle her zaman doğru olmayan bir geometrik inşa gerçekleştirmiştir. Benzer şekilde, ÖA27 de sadece A ve B noktalarından değil daha fazla noktadan pergeli ölçme aracı gibi kullanarak $\mathrm{C}$ ve $\mathrm{D}$ benzeri noktalar elde etmiş ve onları birleştirmiştir. Bu yöntemle her ne kadar paralele yakın doğrular elde etme olasılığı artsa da öğretmen adaylarının fark edemediği önemli nokta, yapılan çizimle her zaman paralel doğru inşası elde edilememesi olmuştur.

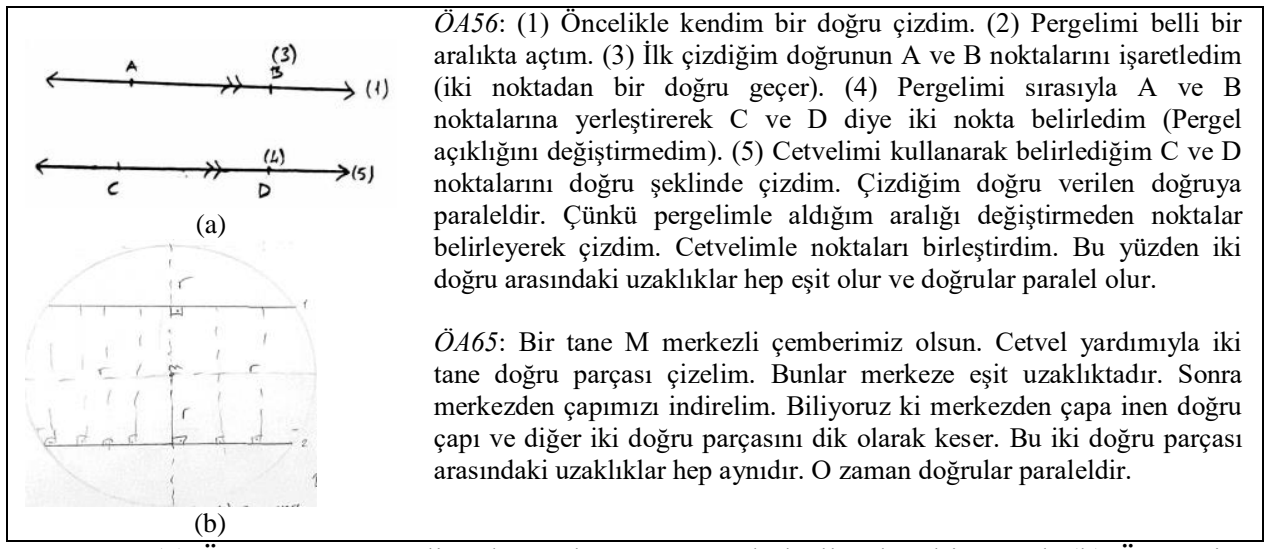

Şekil 6. (a) ÖA56'nın pergeli sadece ölçüm yapmada kullandığı bir örnek (b) ÖA65'in eşit uzunluklu kirişlerle paralellik inşası iddiası

Paralel doğrular arasındaki eşit uzaklık özelliğini temel alan bir öğretmen adayı diğerlerinden farklı olarak çember kirişlerinden yol almaya çalışmıştır (Bkz. Şekil 6-b). ÖA65 yaptığı geometrik inşada çember içine çizdiği kirişlerin birbirine eşit uzaklıkta olduğunu belirtmiştir. Merkezden indirdiği dikmenin iki kirişe birden dik olacağını iddia ederek bu kirişlerin paralel olduğu kanısına varmıştır. Fakat kirişlerin öğretmen adayının yaptığı gibi cetvelle çizerek eşit uzunlukta ve paralel olmasını sağlamak her zaman 
gerçekleşebilecek bir durum değildir. Bu nedenle, öğretmen adayının paralel doğrular arasındaki uzaklığa dayandığı gerekçe doğru olsa da yaptığı inşa paralel doğru oluşturmada yanlış varsayımları yüzünden uygun değildir.

"Bir doğruya dışındaki noktadan yalnız bir paralel doğru çizilir" üzerine kurulan uygun olmayan inşalar: Tablo 5 'te sunulduğu üzere 5 öğretmen adayı bir doğruya dışındaki noktadan yalnız bir paralel doğru çizilir düşüncesi üzerinden hareket ederek paralel doğru inşası yapmaya çalışmış ve başarılı olamamıştır. Bu noktada, öğretmen adaylarının üçü "paralel doğrular arasındaki uzaklık her zaman eşittir" düşüncesiyle yol alarak uygun olmayan paralel inşaları yapan öğretmen adaylarına benzer olarak pergeli bir ölçüm aracı gibi kullanmışlardır. İki noktadan bir doğru geçer postulatını referans alarak önce iki nokta belirleyip bunları cetvelle birleştirmişlerdir. Örneğin, ÖA19 A ve B noktalarını belirleyip bu noktalardan bir doğru çizmiştir. Sonrasında pergelin sivri ucunu A noktasına koyarak açıklığı AB doğru parçası kadar ayarlamıştır ve A' ile B' noktalarını A ve B noktalarının alt tarafına denk gelecek şekilde çizmiştir. Öğretmen adayı, bir doğruya dışındaki bir noktadan bir tane paralel çizileceği gerekçesine dayanarak $[\mathrm{AB}] / /\left[\mathrm{A}^{\prime} \mathrm{B}^{\prime}\right]$ olduğunu ifade etmiştir. Fakat pergel bu iki doğru parçası arasındaki uzaklığın eşit kalmasını garantilemede uygun biçimde kullanılamamıştır. Diğer iki öğretmen adayı ise bir doğru parçasına paralel olan diğer doğru parçasını iki yayın kesim noktasından inşa etmeye çalışmıştır (Bkz. Şekil 7). Esasında ÖA50'nin yaptığ 1 çizimde ikinci bir eşkenar üçgen şekilde görülen eşkenar üçgenin altına tabanları ortak olacak biçimde eklense eşkenar dörtgen yönteminden rahatlıkla paralel doğrular elde dilebilirdi. Diğer taraftan, ÖA50 [BC]'yi uzatıp üzerinde aynı inşayı tekrarlarsa dik doğrular yöntemiyle de paralel doğrulara ulaşabilirdi. Fakat Şekil 7'de görülen inşa ÖA50'nin tek bir noktadan geçirdiği doğrunun [BC]'ye paralel olduğunu iddia ederken dayanaktan yoksun varsayımlara dayalı hareket ettiğini göstermektedir.

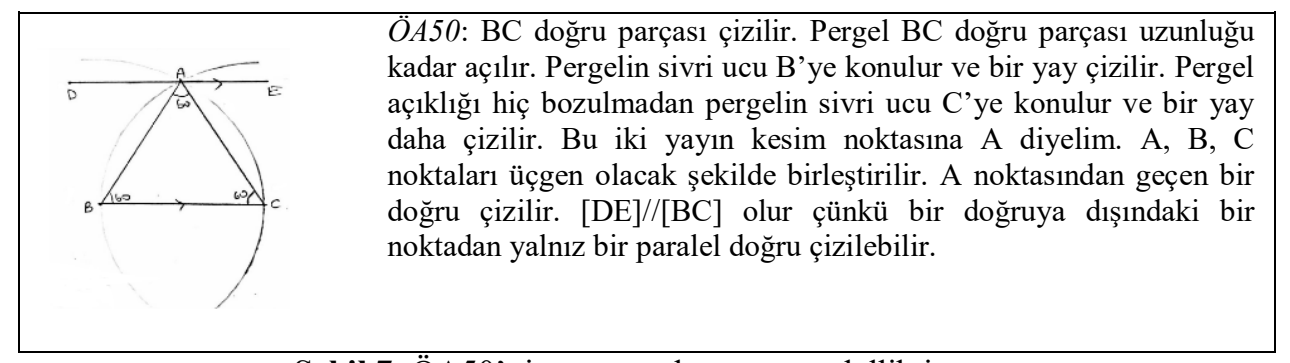

Şekil 7. ÖA50'nin uygun olmayan paralellik inşası

“Paralelkenarın karşılıklı kenarları birbirine paraleldir" üzerine kurulan uygun olmayan inşalar: Uygun olmayan paralellik inşaları içinde gruplanan öğretmen adaylarının ikisi sundukları cevaplarda bir paralelkenar ya da dikdörtgen oluşturmaya çalışarak paralel doğruları elde etme yoluna gitmiştir. Bu dörtgenler ile paralelkenarın karşılıklı kenarlarının birbirine paralel olma gerekçesini öne sürerek oluşturdukları geometrik inşada paralellik olduğunu dile getirmişlerdir. Örneğin, ÖA23 önce cetvelle paralelkenara benzeyen bir dörtgen çizmiştir (Bkz. Şekil 8-a). Ardından, bu dörtgen 
üzerinde pergelle çemberler çizerek denemeler yapmıştır. Yapmaya çalıştığı inşa adımları hakkında yetersiz bilgiler verirken gerekçe olarak şunu dile getirmiştir: "İki eş üçgen için benzerlik teoremi kullanıldığında paralelkenarın köşegenlerinin birbirini ortalayacă̆l ve köşegenlerin açıortay olacağ bilgisi ile paralelkenarın kenarlarının paralel olduğu kanitlanabilir." Bu gerekçeler incelendiğinde herhangi bir paralelkenarda köşegenler her zaman açıortay olmaz. Fakat ÖA23 bu noktada ezbere bir bilgiye yer vermiştir. Diğer taraftan, köşegenlerin ve açırtayın paralel doğru inşasında ne role sahip olduğuna hiç değinilmemiştir. Ayrıca öğretmen adayının kullandığı pergel çizimleri anlamlı bir yapı sunmamaktadır. ÖA43 ise ilk olarak M merkezli bir çember çizmiştir. Ardından, çemberin içinde $d$ ve $l$ doğrularını oluşturduğunu belirtmiştir. "İç ters açılardan $K_{l}=N_{l}$ olur çünkü gördükleri yaylar eşittir" demiştir. Fakat bu yayların nasıl eşit olduklarına dair hiçbir yazılı açıklama sunmamıştır. Çapı gören çevre açıların dikliğini kullanarak kesik çizgilerle belirttiği dörtgenin dikdörtgen olduğunu söylemiştir. Dikdörtgenin karşılıklı kenarlarının paralel olma durumunu öne sürerek paralel doğrulara ulaştığını dile getirmiştir. Maalesef ÖA43 çapı gören çevre açının dikliği ile oluşturduğu her iki üçgenin birleşiminden bir paralelkenar elde edemeyeceğinin farkında olamadığından her zaman geçerli olamayacak bir paralellik inşası sunmuştur (Bkz. Şekil 8-b).

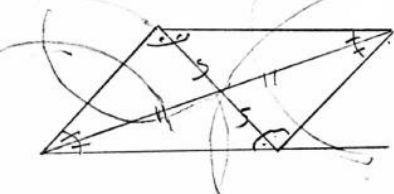

(a)

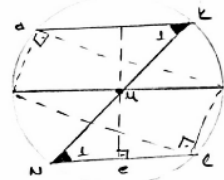

(b)

Şekil 8. (a) ÖA23'ün (b) ÖA43'ün uygun olmayan paralellik inşaları

\section{4. Öğretmen Adayları Fark Ediyor: GeoGebra Kullanımı ve Sınıf Tartışması}

Öğretmen adaylarının yaptığı paralel doğru inşalarının tümü analiz edildikten sonra seçilen cevaplar ve dinamik geometri yazılımı kullanılarak sınıf tartışmaları yürütülmüştür. Öğretmen adaylarının sınıf tartışması ve GeoGebra kullanımı aracılığıyla geometrik inşalarla ilgili neleri nasıl fark ettiği örneklerle bu bölümde sunulmuştur.

\subsubsection{Geometrik inşalar için sağlam dayanaklar sunmanın gerekliliğini fark etme}

Öğretmen adaylarından yaptıkları inşalardan emin olan ve inşa sürecinde gerekçe sunanlar genel olarak sınıf tartışması ve dinamik geometri yazılımı kullanıldığı süreçte geometrik inşalar için sağlam dayanaklar sunmanın önemine tartışma sonrası yansıtıcı düşünme raporunda yer vermemişlerdir. Fakat inşalarında hiç gerekçe sunmayanlar veya uygun olmayan paralel doğru inşaları yapan öğretmen adayları tartışma sonrasında geometrik inşalar için sağlam dayanak sunmanın gerekliliğine değinmiştir. Bazı öğretmen adaylarının yazılı açıklamaları aşağıda sunulmuştur.

ÖA46: Ben sadece çizim adımlarını yazmıştım. Fakat derste gördügüum arkadaşlarım neden öyle bir çizim yaptığını da anlatmış. Adımların sadece inşayı anlattığını ama bir 
inşanın neden doğru olup neden yanlış olduğunu anlatmadı̆̆ını anladım. Nedenleri açıklamak için ise yapılan inşadan emin olmak gerektiğini fark ettim. Ben emin olamadı̆̆ım için gerekçe sunamamıştım.

ÖA30: Ben pergel açıklığını değiştirmedim o yüzden de paralel doğruları buldum dedim. Ama birçok arkadaşım pergel açıklı̆̆ını değiştirmese de yaptı̆̆ inşada paralel doğru inşa elde edememiş. Sadece pergel açıklı̆̆ bozulmadı demek yeterli olmuyormuş onu anladım. Diklik, kenar uzunluğunun aynı olması, yöndeş açılar gibi birçok özellik gerekçe sunmada kullanılması gerekiyormuş.

Öğretmen adaylarının yaptıkları açıklamalar, kiminin yaptığı inşadan emin olmadığ için gerekçeleri yazmadığını ve sadece inşa adımlarına yer verdiğini kiminin ise sadece pergel açıklığını değiştirmeyi bir gerekçe olarak gördüğü için daha fazla açılama yapma gereği duymadığını göstermiştir. Geometrik inşalar için sağlam dayanaklar sunmanın önemini sınıf ortamında fark ettikleri bir anı yansıtan diyalog aşağıda örneklenmiştir. Örneğin, ÖA30 pergel-cetvel ile yaptığı paralellik inşası için sadece pergel açıklığını değiştirmemeyi gerekçe olarak sunmuştu. Fakat sınıf tartışmasında GeoGebra ile inşa tekrar gerçekleştirildiğinde yaptığı inşanın neden paralel doğrular oluşumunu garantilediğini anladı.

Araştırmacı Şimdi senin şeklini GeoGebra'da birlikte inşa edelim.

ÖA30 Önce AB doğru parçasını çiziyorum hocam. İki çemberi de oluşturdum. Şimdi orta dikmeden geçen yani G'den geçen ve diğer iki çemberi kesen üçüncü bir çember oluşturdum (Şekil 9-a).

Araştırmacı Bu şekle göre sen ne demiştin?

ÖA30 Ben $[\mathrm{AB}]$ ile $[\mathrm{JK}]$ paralel olur dedim.

Nerden anlarız paralel olduğunu?

ÖA30 Şekli oynatıyorum paralellik bozulmuyor. Mesela [AB] uzunluğunu değiştirdim çemberler kesiştiği sürece hep paralel doğruları elde edebiliyoruz (Şekil 9-b). Hocam GeoGebra'da paralellik testi de yapabiliriz M noktasındaki doğru [AB]'ye paralel mi diye bakayım.

Araştırmac1 Başka düşüncesi olan var mı?

ÖA18

Aradaki uzaklıklara bakabiliriz. Nasıl bakabiliriz ona?

ÖA49

Bence dikme indirelim doğruların arasına. Aynı uzunluktaysa zaten paralel olur.

ÖA30 Tamam. [JN] ile [KO] aynı uzunlukta çıktı (Şekil 9-c).

ÖA30 arkadaşlarıyla tartışarak kendi inşasını GeoGebra üzerinde gerçekleştirmiştir. İnşayı doğru şekilde aktardıktan sonra paralel doğruları nasıl elde edebileceklerini tartıştıklarında öğretmen adayı ilk olarak programın sağladığı dinamikliği kullanarak şeklin bozulup bozulmadığını kontrol etmiştir. Ardından da yine programın içinde bulunan paralellik kontrol panelini kullanarak $[\mathrm{AB}]$ ile $[\mathrm{JK}]$ doğru parçalarının paralel olup olmadığını kontrol ettiğinde paralel doğruları elde ettiğini emin olmuştur. Diğer taraftan, sınıftaki diğer öğretmen adayları verdikleri önerilerle paralelliği gerekçelendirmede başka argümanların da kullanılacağını ifade etmişlerdir. Böylece, iki doğru parçası arasına indirilen dikmelerin uzunluğunu kontrol ederek paralel doğruların 
varlığından emin olmuşlardır. Yazdıkları raporlarda, öğretmen adayları farklı argümanlar kullanarak gerekçelendirdiklerinde inşaları ve altında yatan nedenleri daha iyi anladıklarını da belirtmişlerdir. Bu sebeple, sağlam gerekçeler sunabilmenin bir geometrik inşayı anlamada önemli bir yere sahip olduğu sonucuna varmışlardır.

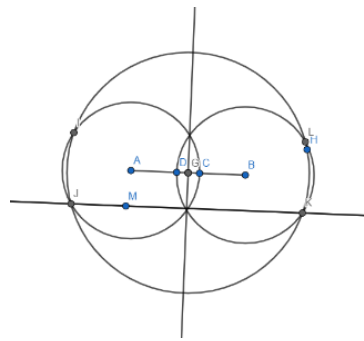

(a)

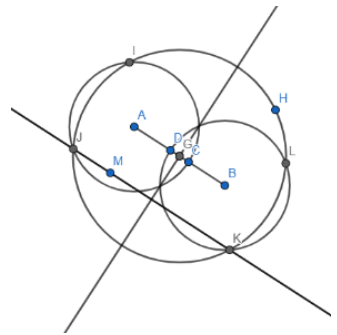

(b)

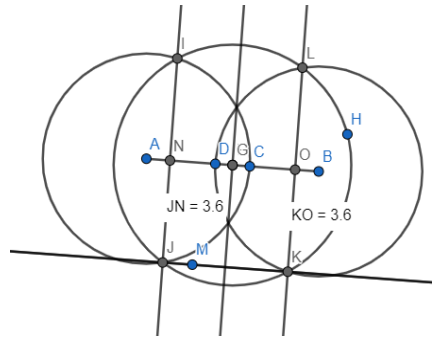

(c)

Şekil 9. ÖA30'un GeoGebra'da [AB] ile [JK]'nin paralel olduğuna dair inşası

\subsubsection{Yanlış varsayımların geometrik inşalardaki etkisini fark etme}

Daha önce belirtildiği üzere öğretmen adaylarının \%52'si paralel doğru özelliklerini kullanarak yanlış varsayımlara dayalı uygun olmayan geometrik inşalar gerçekleştirmiştir. $\mathrm{Bu}$ öğretmen adaylarının nerdeyse hepsi hem sınıf tartışma sürecinde hem de tartışma sonrası yansıtıcı düşünme raporlarında yaptıkları yanlış varsayımların inşalarında sorun oluşturduğunu fark ettiklerini belirtmişlerdir. Bu farkındalığ 1 kazanmalarında GeoGebra üzerinde belli inşaları yeniden oluşturmanın ve sınıfça tartışmanın en önemli etken olduğunu dile getirmişlerdir. Öğretmen adaylarının yanlış varsayımların paralel doğrular inşasında neye yol açtığını inceledikleri bazı sınıf tartışma örnek kesitleri aşağıda sunulmuştur.

Şekil 2'de geometrik inşası sunulan ÖA24 kendi geometrik inşasını dinamik geometri yazılımı üzerinde gerçekleştirdi. Bunun için ilk olarak A noktasından geçen ve B merkezine sahip bir çember oluşturdu (Şekil 10-a). Sonrasında bir C noktası bir E noktası işaretledi. "Bu noktadan doğru çizmem lazım" dedi. Fakat bu esnada tek bir noktanın doğru inşa etmede yetersiz olduğunu tüm sinıfla birlikte fark etti. Bu yüzden kareleri sayarak GeoGebra'da $C$ ve $E$ ile aynı hizada olduğunu düşündüğü $D$ ve $F$ noktalarını belirledi. Ardından $\mathrm{C}$ ve $\mathrm{D}$ den geçen bir doğru ile $\mathrm{E}$ ve F'den geçen bir doğru çizdi. $\mathrm{Bu}$ doğruların da teğetlik nedeniyle paralel olduğunu ifade etti. Bu süreçte verilen diyalogdaki konuşmalar gerçekleşmiştir.

ÖA24

Araştırmacı

ÖA31

ÖA37

ÖA24

Araştırmacı
Burada teğet olduğu için bu iki doğru paralel olur.

Arkadaşlar sizce paralel olur mu?

Hocam sadece dikse olur. Diğer türlü nasıl emin olacağız ki?

Hocam bence bir şekli oynatalım.

Şekil bozuldu. Paralel olmuyor mu yani? Ama neden? (Şekil 10-b)

Sence neden olmadi? 
ÖA60 Hocam bence D ve F noktalarını biraz keyfi belirlediği için olmuyor. Şeklin kaymaması için o noktalar sabit olmalıydı.

ÖA31 Bence de. Göz kararı olmaz.

Araştırmacı Peki, nasıl gösterebiliriz paralelliği?

ÖA24 Birkaç tane çember çizip onların kesişim noktalarını mı birleştirsem acaba?

$\mathrm{Bu}$ diyalogda, ÖA24'ün GeoGebra'da da pergel-cetvel kullanarak yaptığı inşaya benzer bir inşa yapmaya çalıştığ görülmektedir. Fakat öğretmen adayı, yaptığı inşada programın sadece bir noktadan bir doğru çizmeye izin vermediğini fark etmiştir. Bu sayede sınıfta ikişer nokta olması gerektiği kanısına varmışlardır. ÖA24 noktaların belirlenmesinde programdaki kareli zemin üzerinden DC ve FE doğru parçalarını paralel olacak biçimde ayarlamaya çalışıp bu doğru parçalarının paralel olduğunu iddia etmiştir. Fakat programın dinamiklik özeliğini kullandığında öğretmen adayı ve sınıf arkadaşları yapılan geometrik inşanın ve teğetlik ve diklik varsayımlarının bu inşada gerçekleşmediğini fark etmişlerdir. Bu noktada, hatanın kaynağının da rastgele belirlenen $\mathrm{D}$ ve $\mathrm{F}$ noktalarından kaynaklandığ 1 sonucuna vardılar. Bu aşamalar, tüm öğretmen adaylarının yanlış varsayımların ve keyfi belirlenen durumların geometrik inşadaki etkini anlamaları için önemli olmuştur.

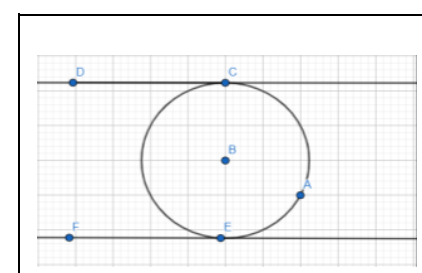

(a)

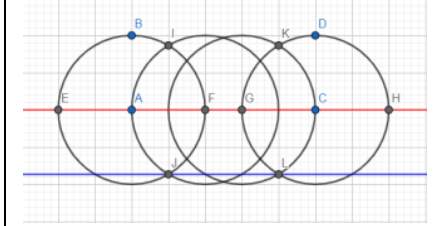

(c)

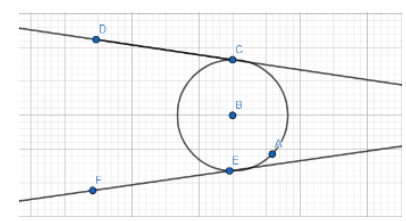

(b)

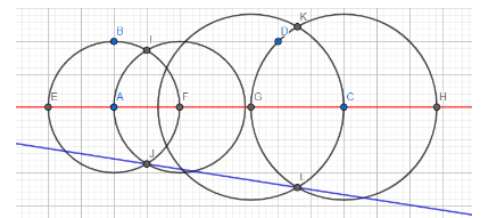

(d)

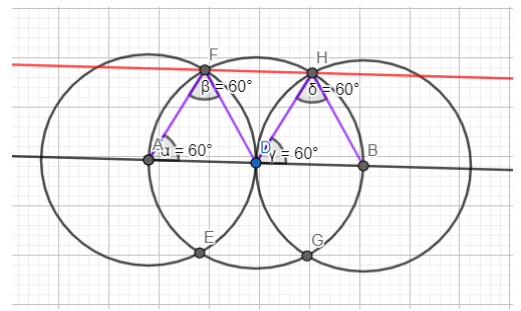

(e)

Şekil 10. ÖA24'ün GeoGebra'da sınıf arkadaşlarıyla birlikte yaptığı geometrik inşalar 
Tartışmanın devamında, ÖA24 yeni bir yol ile inşa sürecine yeniden başlamaya karar vermiştir. Bunun için aynı doğru üzerinde birkaç tane eş çember inşa etmenin gerekli olduğu kanısına vararak Şekil 10-c'deki geometrik inşayı gerçekleştirmiştir. Önce A merkezli B'den geçen bir çember ile ardından C merkezli ve D'den geçen bir çember inşa etmiştir. Sonrasında F merkezli A'dan geçen bir çember ile G merkezli C'den geçen bir çember oluşturmuş̧tur. Çemberlerin kesişim noktalarını belirleyerek ikinci doğruyu ortaya çıkarmıştır. Fakat öğretmen adayı şekli oynattığında Şekil 10-d'deki gibi bozulma olduğunu sınıfça görmüşlerdir ve yapılan inşada hata olduğunu anlamışlardır. Bu hatanın nedenine şu şekilde varmışlardır:

ÖA24 Yine nerede hata yaptım?

Araştırmacı Sizce nerede hata var?

ÖA55 Hocam sanırım tüm çemberler eş değil.

ÖA24 İkişer ikişer eş olmuşlar ondan bozuluyor.

Araştırmacı Tüm çemberleri nasıl eş yapabiliriz?

ÖA37 Üç çember yeterli. Ben öyle yapmıştım. İki çemberi birbirine teğet ve eş, üçüncü çemberi de teğet noktası merkez olacak şekilde eş çizersek olur.

Verilen diyalogda görüldüğü üzere, sınıf tartışmasında yapılan inşa dinamik ortamda bozulunca sıkıntının çemberlerin eş olmamasıyla ilgili olduğunu anlamışlardır. Bunun üzerine ÖA24 arkadaşlarının yardımıyla Şekil 10-e'de geometrik inşayı gerçekleştirmiştir. Çemberlerin kesim noktaları $\mathrm{F}$ ve H'yi birleştirdiğinde [AB] ile [FH]'nin paralel olduğundan emin olmuşlardır. Çünkü şekilde hiçbir bozulma olmadığını teyit etmişlerdir. Araştırmacı şekil bozulmamasına ek olarak paralelliğin varlığından nasıl emin olunacağını sorduğunda, öğretmen adaylarından biri eşkenar üçgen yöntemi ile kontrol etmeyi önermiştir. Bunun üzerine Şekil 10-e'deki gibi noktalar birleştirilerek üçgenler oluşturulmuştur ve bu üçgenlerin iç açıları ölçüldügünde eşkenar iki eş üçgen olduğu sonucuna varılmıştır. Öğretmen adaylarının bazıları bu üçgenlerin yükseklikleri eşit uzunlukta olduğundan yola çıkarak bazıları ise yöndeş açıların eş olması üzerinden paralel doğrular inşasından emin olmuşlardır.

Benzer bir farkındalık süreci ÖAl'in geometrik inşasının analizi esnasında daha oluşmuştur. ÖA1 Şekil 2-a'da da gösterildiği gibi pergel-cetvel ile yaptığ1 inşada birbirlerinin merkezinden geçen iki eş çemberin merkez noktalarından uzanan doğruların paralel olduğunu iddia etmişti. Aynı inşayı GeoGebra üzerinde oluşturduğunda (Şekil 11a) ve şekli hareket ettirdiğinde inşanın bozulduğunu sınıfça görmüşlerdir (Şekil 11-b). Bu inşada da sorunun $\mathrm{E}$ ve $\mathrm{C}$ noktalarının keyfi belirlenmesinden kaynaklı olduğunu ve A ve B'den teğet doğru çizmenin paralelliği garantilemede yetmediğini anlamışlardır. Bunun üzerine, eşkenar dörtgen yöntemini kullanarak ispat yapan öğretmen adaylarından biri çemberlerin kesim noktaları ile merkezlerini birleştirilmesinin mantıklı olduğunu belirtmiştir. Böylece Şekil 11-c'deki inşa gerçekleştirilerek paralel doğrular elde edilmiştir. İnşa doğruluğunu teyit etmek için hem şekli hareket ettirmişler hem de açıları ölçerek sonuca varmışlardır. 


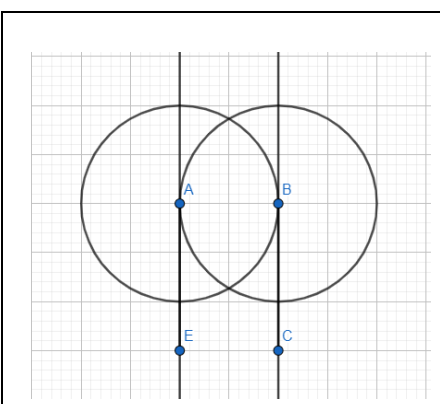

(a)

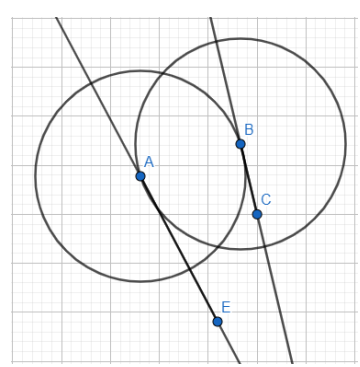

(b)

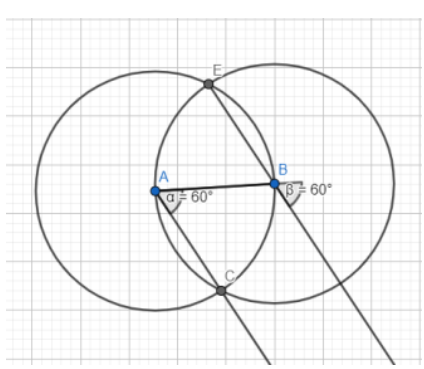

(c)

Şekil 11. ÖA1'in GeoGebra'da sınıf arkadaşlarıyla birlikte yaptığı geometrik inşalar

Sonuç olarak, öğretmen adayları yansıtıcı düşünme raporlarında varsayımların inşalar üzerindeki etkisini şu şekilde ifade etmeye çalışmışlardır. Örneğin, ÖA4, "Ben teğetlik işe yarar diye bir noktadan teğet çizdim oldu sanıyorum. Ama şekil bozuluyor hep. Anladım ki teğet olma tek başına paralelliği garantilemiyor. Çünkü teğet noktada çapa dik doğru çizememişim." derken ÖA1, "Arkadaşlarım ve şekil hareket ettirilmesi sayesinde birçok şeyi anladım. Ben bir noktadan doğruyu çizmiştim. Fakat gördüm ki iki noktadan bir doğru geçiyor. Benim böyle de olur dediğim şeyler hep yanlış çıtkt." diye yazılı açıklamada bulunarak yaptıkları varsayımların inşaları üzerine nasıl etki ettiğini anlamışlardır.

\subsubsection{Alternatif inşa yöntemlerini fark etme}

Öğretmen adaylarının tamamı, yazdıkları yansıtıcı düşünme raporunda sınıfta yapılan tartışma sonunda paralellik inşasında tek bir yol olmadığını birçok farklı ve kullanışlı yol olduğunu fark ettiğini belirtmiştir. $\mathrm{Bu}$ durumu örneklemek için eşkenar dörtgeni yönteminin ele alındığı sınıf tartışma sürecinden şöyle bir diyalog sunulabilir.

Araştırmacı İki arkadaşınızdan birinin cevabını görüyorsunuz. Arkadaşınız bize bu yöntemle nasıl inşa yaptığını anlatacak şimdi (Bkz. ÖA34-Tablo 3).

ÖA34 Hocam benim aklıma eşkenar dörtgen şekli geldi. Biz ispat yaparken eşkenar dörtgenden çok yararlanmıştık. Bu yüzden, iki eşkenar üçgen elde etsem bir eşkenar dörtgen de elde edebilirim diye düşündüm.

ÖA50 Çok kolay ve güzel bir yöntemmiş. Ben üçgenin birini çizmiştim. Altına da üçgen eklesem olacaktı demek ki.

ÖA5 Benim aklıma hiç gelmedi. Diklik kullanarak yapmıştım ben. Keşke böyle yapsaydım.

ÖA40 Benim aklıma geldi ama pergelle yapamadım nasıl oluşturacağımı bilemedim.

Sınıf tartışmasında görüldüğü üzere eşkenar dörtgen yöntemi ile paralel doğru inşası öğretmen adayları tarafından çok kolay ve kullanışlı bulunmuştur. Hatta bu konuda ÖA50 kendi geometrik inşasındaki eksikliği fark edebilmiştir. Dinamik geometri yazılımında eşkenar dörtgen yöntemi kullanılarak yapılan inşada ise açıların eş olduğu oluşan şeklin 
bir dörtgen olduğu gösterilince, öğretmen adayları bu yöntemin nasıl kullanıldığını ve gerekçelendirildiğini anlamışlardır. Bu konuda yazılı gerekçelerde şu tip cümleler kurmuşlardır: "Ben eşkenar dörtgen yöntemini çok beğendim. Onun dışında diklik ile nasıl paralellik inşası yapılır gördüm. Bu bilgiler benim pergel ve cetvelin nasıl birçok yönden kullanılacağını anlamamı sağladı (ÖA1)". Diğer bir öğretmen adayı ise şu şekilde bir yazılı açıklama sunmuştur: "Ben cetvel ve pergel ile inşa yapmayı ilk kez bu derste ögrendim. Önce sadece adımların uygulandığ birer materyal diye düşünmüştüm. Ama ispatlar yaptıkça, pergel ve cetvelin birçok yolla inşa yapmayı sağladı̆̆ını fark ettim." Yapılan açıklamalar gösteriyor ki sınıf tartışmaları ve dinamik geometri yazılımları sayesinde öğretmen adayları paralel doğruların birçok farklı yöntemle elde edilebileceğini fark etmişlerdir.

\subsubsection{GeoGebra ve pergel-cetvelin geometrik inşa ve ispatlamadaki rolünü fark etme}

Öğretmen adaylarının yansıtıcı düşünme raporlarında sıklıkla dile getirdikleri diğer önemli bir konu dinamik geometri yazılımı ile pergel-cetvel inşalarındaki inşa süreci ve doğrulama adımlarında farklı rollere sahip olduklarını fark etmeleri olmuştur. Genel olarak, öğretmen adayları her iki öğretim materyalinin inşa sürecindeki olumlu ve olumsuz yönlerine atıf vermişlerdir. Örneğin, öğretmen adaylarının bazıları pergel ve cetvel inşalarında bir şekli hareket ettirmenin mümkün olmadığını belirterek bunun inşayı doğrulamada sorun yarattığını belirtmiştir. Fakat bu düşünceye zit olarak bazı öğretmen adayları, dinamik geometri yazılımında paralellik, diklik ve diğer birçok konu otomatik olarak sağlanabildiği için bunlar altında yatan nedenleri sorgulamanın zor olduğunu dile getirmiştir. $\mathrm{Bu}$ bakımdan pergel ve cetvel kullanımının geometrik inşa yapmada kendilerini daha fazla matematiksel düşünmeye ittiklerini belirtmişlerdir. Diğer taraftan, bazı öğretmen adayları ise her iki öğretim materyalinin de inşa sürecinde kullanılmasının kendilerinde çok büyük farkındalık yarattığını söylemiştir. Özellikle yanlış varsayıma dayanarak inşa yaptıklarını anlama açısından önce pergel-cetvel ve ardından dinamik geometri yazılımı kullanmanın etkili olduğunu iddia etmişlerdir. Öğretmen adaylarının bazılarının yazılı açıklamaları aşağıda yer almaktadır.

ÖA65: Ben pergel ile yaptı̆̆ım inşadan emindim. Ama öyle şeyleri baştan kabul etmişim ki yaptı̆̆ım inşa programda çizince yanlış oldu. $O$ anda yeniden pergelle denedim ve hatamı buldum. Ben ilk programda yapsaydım bence bu kadar iyi ögrenemezdim.

ÖA15: Sadece cetvel kullanıp öylesine çizdiğim bir şeydi paralellik. İspat edememiştim. Ben programda inşa et deseler orada bir nokta bir doğru çizerdim. Paralel inşa tuşuna basardım direk çizim olurdu zaten. Ama pergel ve cetvel değişik materyaller bence. Çünkü çok farklı şeyler çizerek birçok yolla paralel inşasını onlar sayesinde anladım. Bunda arkadaşlarımın cevaplarını görmek de çok faydalı oldu.

Öğretmen adaylarının yaptıkları açıklamalar, onların paralel doğru inşalarının pergelcetvel ve dinamik geometri yazılımı ile yapılmasının inşa sürecindeki düşünceleri üzerine nasıl etki ettiği ve bu anlamda neleri fark ettiklerini yansıtmaktadır. Vurguladıkları temel noktalardan biri de sınıf tartışmasının ve farklı yöntemlerin paylaşımının geometrik düşünmelerine olan olumlu etkisi olmuştur. 


\section{Tartışma ve Sonuç}

$\mathrm{Bu}$ araştırmada, öğretmen adaylarının pergel ve birimsiz cetvel aracılığıyla paralel doğru inşasını nasıl gerçekleştirdikleri ve gerekçelendirdikleri incelenmiştir. Ek olarak, öğretmen adaylarının yaptıkları inşaları sınıf ortamında GeoGebra yazılımı ile inceledikleri süreçte geometrik inşa ve gerekçelendirme bakımından neleri fark ettikleri analiz edilmiştir. Öğretmen adaylarının pergel ve cetvel kullanarak yaptıkları uygun paralellik inşaları incelendiğinde, (i) dik doğrular, (ii) eşkenar üçgenler, (iii) eşkenar dörtgen ve (iv) açı taşıma yöntemleri olmak üzere dört farklı yöntemi tercih ettikleri ortaya çıkmıştır. Elde edilen sonuçlara göre, dik doğrular ve eşkenar üçgen yöntemleri paralel doğruların inşasında en fazla tercih edilen yöntemler olurken, eşkenar dörtgen ve açı taşıma yöntemleri oldukça az sayıda öğretmen adayı tarafindan tercih edilmiştir. $\mathrm{Bu}$ noktada, kitap ve internet kaynakları incelendiğinde paralel doğruların inşası için dik doğrular yönteminin sıklıkla kullanıldığı dikkat çekmektedir (Collaborate, Plan, Align, Learn, Motivate, and Share [CPALMS], 2019; Freeman, 2010). Ayrıca öğretmen adaylarının çoğunluğunun dik doğrular kullanarak paralel inşa yapmaya çalışmalarının temel sebebi, veri toplama süreci öncesinde aldıkları temel geometrik kavram ve inşa bilgileri ile ilgili olduğu düşünülebilir. Çünkü öğretmen adayları doğru parçası taşıma, açı taşıma, eşkenar üçgen oluşturma, bir doğruya dışından veya üzerinden dikme indirme ve bir doğru parçasının orta dikmesini bulma gibi temel inşaları veri toplama süreci öncesinde öğrenmişlerdir. $\mathrm{Bu}$ ön öğrenme onların pergel ve cetvel ile yapabildikleri inşalar ile paralel doğrular inşası arasında ilişki kurmalarına yardım etmiştir. Bu sayede, bilinen bir yöntemin inşa adımlarını ezbere uygulamaktan ziyade, edindikleri inşa bilgileri ile uygun yöntemin ne olabileceğini kendileri keşfetmişlerdir. Bu noktada, Karakuş (2014) yaptığ 1 çalışmada öğretmen adaylarının geometrik inşa etkinliklerinde en çok pergel kullanma konusunda zorluk çektikleri sonucuna varmış ve bu durumu geçmişte pergelcetvel inşası yapmamaları ile ilişkilendirmiştir. Fakat bu araştırmada edinilen sonuçlar öğretmen adaylarının büyük bir kısmının pergel ile inşa yapmaya çalıştığını ve pergeli kullanmakta belirtildiği kadar büyük bir zorluk yaşamadığını göstermiştir. Bu durumun en önemli sebeplerinden biri, yine öğretmen adaylarının paralellik inşalarına başlamadan önce temel geometrik inşa bilgilerini edinmeleri ile ilişkilidir. $\mathrm{Bu}$ durum, öğretmen adaylarına geometrik inşalarla ilgili tecrübe edinebilecekleri ortamları ve firsatları sunmanın faydalarını ve gerekliliğini işaret etmektedir.

Araştırmada ulaşılan önemli sonuçlardan bir diğeri ise öğretmen adaylarının yarısından fazlasının pergel ve cetvel ile paralellik inşasında uygun olmayan geometrik inşalar oluşturmaları olarak ortaya çıkmıştır. İlginç olan ise bu öğretmen adaylarının paralellik ile ilgili sıralanan özelliklere odaklanmalarına rağmen hatalar yapmış olmalarıdır. Bu özellikler, (i) aynı doğruya dik olan iki doğru birbirine paraleldir, (ii) yöndeş açıların ölçüsü eşit ise doğrular paraleldir, (iii) paralel doğrular arasındaki uzaklık her zaman eşittir, (iv) bir doğruya dışındaki noktadan sadece bir paralel doğru çizilir ve (v) paralelkenarın karşılıklı kenarları birbirine paraleldir. Aslında bu özelliklerin paralellik inşalarında kullanılan diklik, açı taşıma, eşkenar üçgen ve eşkenar dörtgen yöntemleriyle ilişki olduğu görülmektedir. Fakat yapılan açıklamalar ve inşalar öğretmen adaylarının doğru paralellik özelliklerden gitmelerine rağmen inşalarında hatalar olduğunu 
göstermiştir. Öçal ve Şimşek (2017), inşalarda yapılan hataların temelinde istenilen inşaların yapılış basamaklarında atlamalar veya bazı basamakların yapılışı sırasında değişiklikler yapmak olduğunu öne sürmüştür. Fakat bu araştırmada, öğretmen adaylarının yaptığı inşa hatalarının temelinde genel olarak hatalı varsayımlara dayalı hareket etmeleri yatmaktadır. Örneğin, eş çemberlerin kesişim noktalarından çizilen doğrular paralel olur veya çembere teğet olan doğrular paralel olur veya çap merkez üzerindeki bir noktadan geçen geçen doğruya dik olacak şekilde çizilir gibi inşa öncesi zihinlerinde varsaydıkları durumlar nedeniyle her zaman geçerli olmayacak bir paralellik inşası gerçekleştirmişlerdir. Bu konuda, birçok çalışma, öğretmenlerin geometrik inşa çalışmalarının amacı ve anlamını bilmediklerini ve geometrik inşalar yaparken ezbere sadece adımları uygulayarak hareket ettiklerini belirtmektedir (ör., Erduran ve Yeşildere, 2010; Karakuş, 2014). Bu durum için araştırmacılar önceki öğrenme süreçlerinde pergel ve cetvel ile inşa uygulamalarına yer verilmemesini neden olarak göstermektedirler. Benzer şekilde, bu araştırmada da öğretmen adaylarının büyük bir çoğunluğu çalışmanın başlangıcında öğrenim hayatları boyunca hiç pergel-cetvel inşaları ve GeoGebra'da gerçekleşen geometrik inşalarla karşılaşmadıklarını dile getirmişlerdir. Bu anlamda, Öklid inşalarında birimsiz cetvel ve pergel kullanımı öngörülse de pergel-cetvel inşalarına alışık olmayan bazı öğretmen adayları sadece cetvel kullanarak inşadan ziyade bir çizim yapmıştır. Bazı öğretmen adayları ise pergeli cetvelle ölçemediği uzaklıklara karar vermek için cetvel gibi kullanmaya çalışmıştır. Öçal ve Şimşek 'in (2017) çalışmasında vardığı sonuca benzer biçimde bazı ögretmen adayları pergelde aldıkları referans noktalara göre her zaman doğru olmayacak inşalar gerçekleştirmişlerdir.

Öğretmen adaylarına bireysel olarak pergel ve cetvelle yaptırılan paralellik inşalarında onların ne tip yöntemleri tercih ettikleri, ne gibi özelikleri kullanarak yol aldıkları ve inşaların hangi aşamalarından neden zorluk yaşadıkları tüm detayıyla ortaya çıkmıştır. $\mathrm{Bu}$ bilgilerin ışı̆̆ında dinamik yazılım kullanılarak yapılan sınıf tartışmaları, öğretmen adaylarının geometrik inşa ve gerekçe sunma konusunda farkındalıklarını arttırmada önemli roller üstlenmiştir. Sonuçlar, öğretmen adaylarının geometrik inşaları çeşitli bakımdan fark ettiklerini ortaya çıkarmıştır. Bunlar; (i) geometrik inşalar için sağlam dayanaklar sunmanın gerekliliğini fark etme, (ii) yanlış varsayımların geometrik inşalardaki etkisini fark etme, (iii) alternatif inşa yöntemlerini fark etme ve (iv) dinamik geometri yazılımı ile pergel-cetvelin geometrik inşa ve ispatlamadaki rolünü fark etme olarak sıralanabilir. Bu farkındalıkların kazanılmasında hem iki öğretim materyalinin sıralı kullanımı hem de sınıfta tartışmalarla yapılan ispat yolunun etkili olduğu düşünülmektedir. Bu sayede, öğretmen adayları sadece bir öğretim materyalini kullanarak o materyale karşı belli bir tutum geliştirmemiştir. Aksine her iki öğrenme aracında paralellik inşa ve gerekçelendirme sürecinin nasıl işlediğini kavramsal anlamda da görebilmişlerdir. Normalde, ilgili alan yazındaki birçok araştırma, öğretmen adaylarının pergel ve cetvel kullanılarak yapılan inşalara karşı olumlu tutum sergiledikleri sonucuna varmıştır (Cheung, 2011; Çiftçi ve Tatar, 2014; Erduran ve Yeşildere, 2010; Gür ve Kobak-Demir, 2017; Karakuş, 2014; Napitupulu, 2001). Fakat bazı çalışmalarda ise katılımcıların pergelle yapılan inşaları gereksiz ve anlamsız bulduğunu, öğrenilecek konuyu zorlaştıracağını düşündüğünü (Karakuş, 2014) ve öğrencilerin konuya olan 
ilgilerini azalttığını belirten bulgulara rastlanmaktadır (Güven, 2006). Diğer taraftan, sadece dinamik yazılımların kullanıldığ 1 çalışmalarda ise öğrenciler için keşfe dayalı öğrenme ortamları yarattığı ve inşa süreçlerinde belli zorluklar yaşansa bile geometri konularında öğrenmeyi desteklediği bulgularına ulaşılmıştır (Bokosmaty, Mavilidi \& Paas, 2017; Bozkurt, 2018). Bu araştırmada elde edilen sonuçlar alan yazında konu ile ilgili ulaşılan sonuçlara göre farklılık taşımaktadır. Çünkü bu çalışmada, öğretmen adaylarının pergel-cetvel inşaları ile dinamik yazılımı birlikte kullanma firsatı yakalamış olmaları onlara her iki öğretim materyalini inşa ve ispatlama bakımından kıyaslama imkânı sunmuştur. Bu bakımdan, öğretmen adayları sadece pergel-cetvel ile belli inşaları adımlara göre bireysel olarak uygulamak gibi yavan bir süreçten geçmemiştir. Aksine, yaptıkları inşaları belli gerekçelerle savunmaya çalışmışlar ve dinamik yazılım üzerinde yeniden inşa ederek sınıfça kritik etmişlerdir. Bu sayede, diğer çalışmalarda olduğu gibi pergel-cetvel inşaları doğrudan gerekli veya gereksiz diye değerlendirmek yerine, iki öğretim materyalinin inşa ve ispatlamadaki rolünü fark ederek onların olumlu ve olumsuz yönlerini ele almışlardır. Bu konuda, birçok çalışma GeoGebra kullanmanın, çizimlerde dinamiklik sağladığı, verilen cevapları doğrulamada kolaylık sağladığı, şekildeki ilişkileri daha kolay görmeyi sağladığını ve zamanda tasarruf sağladığını belirtmiştir (Çiftçi ve Tatar, 2014; Jones, 2000; Hohenwarter, Hohenwarter \& Lavicza, 2010; Tatar, Kağızmanlı ve Akkaya, 2014).

Diğer taraftan, araştırmacılar GeoGebra kullanımının dezavantajları olduğu sonucuna da varmışlardır. Bunlar, öğretmen adaylarının aynı hızda ilerleyememesi, programın belli özellikleri nedeniyle gerekçe sunmada kendilerini çok çabuk ikna etmeleri, derinlemesine muhakeme yapmamaları ve sınıf̧̧a argüman sunulduğu için her öğretmen adayının aktif katılım gerçekleştirememesi olarak sıralanmıştır. Benzer sonuçlara bu araştırmada da ulaşılmıştır. Örneğin, diğer bazı çalışmalarda olduğu gibi (De Villiers, 2003) bu çalışmada da öğretmen adayları GeoGebra ile yaptıkları inşalarda sadece şekli hareket ettirmeyi veya doğru parçaları arasındaki uzaklığı ölçmeyi paralelliğin sağlandığını anlamada gerekçeler olarak kullanmıştır. Fakat sınıf̧̧a yapılan tartışmalar, pergel-cetvel inşalarında çeşitli yöntemleri kullanan öğretmen adaylarının fikir paylaşımlarıyla öğretmen adaylarını GeoGebra ile inşa sürecinde daha sağlam gerekçeler sunma yönünde desteklemiş̧ir. $\mathrm{Bu}$ açıdan, yapılan bu araştırma pergel-cetvel ve dinamik geometri yazılımının aşamalı birbirini destekler nitelikte kullanımının öğretmen adaylarının öğrenme materyallerinin farklı özelliklerini kıyaslayarak daha iyi anlamasına sağladığı katkıları gösterme adına önem taşımaktadır. Bu konuda Çiftçi ve Tatar (2014) da dinamik geometri yazılımı kullanımının pergel-cetvel kullanımına göre akademik başarı açısından anlamlı bir farklılığa neden olmadığı sonucuna varmıştır. Her iki öğrenme materyalinin de öğrenmeye sağladığ1 katkı ve bu çalışmada varılan sonuçlar düşünüldüğünde geometrik inşa becerilerini desteklemede hem pergel-cetvel hem de dinamik geometri yazılımının sistemli kullanımının faydalı olacağı düşünülmektedir. Ayrıca bazı çalışmalarda sınıf ortamının kalabalık olması gibi birçok gerekçe nedeniyle öğretmenlerin materyalleri sınıfta kullanmadığ 1 sonucuna varılmaktadır (ör. Güneş ve Baki, 2011). Bu araştırmada sınıflar kalabalık olmasına rağmen sistematik bir uygulama yaklaşımı belirlendiği için öğretmen adaylarının öğrenmesinin desteklenmesinde büyük bir sorunla 
karşılaşılmamıştır. $\mathrm{Bu}$ yönüyle, araştırmada kullanılan uygulama biçimi bu konuda çalışma yapmayı planlayan araştırmacılara ilham verebilir. 


\section{Prospective Mathematics Teachers' Geometric Constructions Using Compass-Straightedge and Dynamic Geometry Software}

\section{Extended Abstract}

\section{Introduction}

Euclidean geometry is considered as the geometry of the shapes that can be drawn through a compass and a unitless ruler (Axler \& Ribet, 2005; Stillwell, 2005). In geometric construction process, the aim is to find a solution to a geometric problem rather than to obtain certain shapes by applying a procedure using compass and ruler (Erduran \& Yeşildere, 2010; Napitupulu, 2001). In constructions made with a ruler and a compass, it is necessary for the individual to both use the materials psycho-motor skills and to understand the construction process cognitively (Altun, 2015). Because it is not possible to decide where to start the construction work at first, geometric construction process creates a problem situation and necessitates the use of mathematical skills (Erduran \& Yeşildere, 2010). Thus, students have the opportunity to apply many concepts and features they learn by using high-level thinking skills such as analysis, evaluation, hypothesis building and organizing in geometric construction tasks (Lim-Teo, 1997). There are many examples of basic constructions in Euclidean geometry (e.g., perpendicularity and parallelism) (Smart, 1993). In the area of learning geometry, most concepts generally depend on lower level concepts. For example, among geometric concepts in Euclidian geometry, the parallelism of line segments has critical importance in terms of developing learners' ideas about the concepts of quadrilaterals, angle, distance as well as developing students' proficiency in providing proof, argumentation and generalization (e.g. Mansfield \& Happs, 1992). However, studies indicated that students have various difficulties in learning parallelism concept (Abravanel, 1977; Gal, 2011; Ulusoy, 2016; Ulusoy \& Çakıroğlu, 2017).

Students' understanding is highly related to how teachers address concepts in their lessons. Teaching of basic geometric constructions is explicitly emphasized in elementary mathematics curriculum and secondary school textbook contents. At this point, teachers need to have sufficient knowledge and skills about geometrical constructions. With this awareness, in recent years, studies have been carried out to understand (prospective) teachers' thoughts, attitudes and achievements about geometric construction in Turkey. Studies showed that teachers and prospective teachers generally have positive attitude towards the compass-ruler construction, but they followed a memorizing path in the construction process or they have not been successful enough in forming the desired construction (Bozkurt, 2018; Erduran \& Yeşildere, 2010; Gür \& Kobak-Demir, 2017; Öçal \& Şimşek, 2017). These studies show that teacher candidates have deficiencies in this subject and these shortcomings need to be eliminated. For this reason, this study aimed to investigate prospective middle school mathematics teachers' geometric constructions and justifications of parallelism when they use compass-straightedge. In addition, it was examined what prospective teachers noticed about geometric constructions in a classroom discussion where dynamic mathematics software (GeoGebra) was used. In this sense, 
following research question guided this study: (1) How and by which methods do prospective middle school mathematics teachers construct parallelism using ruler and compass? (2) What do they notice about the geometric constructions in classroom discussions in a dynamic geometry software (GeoGebra) supported environment?

\section{Method}

A holistic single case study design (Yin, 2013) has been adopted in this study as it is a single case study of the cases related to prospective teachers' geometric constructions. A total of 68 prospective teachers from middle school mathematics teacher education program participated to the study. Data were obtained by qualitative research ways such as written papers, reflective notes, and classroom discussions. First, participants were trained about how they can use compass-ruler and GeoGebra in constructions in Geometry course. Before beginning data collection, participants learned constructions of angle, equilateral triangle, angle bisector, perpendicularity, perpendicular bisector by using compass and ruler. After the seventh week of the course, participants were asked to construct parallel line segments using compass and ruler individually. They were also asked to write how she/he constructed and the reasons why she/he thought her/his construction provided parallelism. The researcher examined all constructions and written explanations. In the following week, a classroom discussion was held in GeoGebra-supported learning environment. Some participants' compass and ruler constructions were selected and discussed on GeoGebra in terms of the method used, correctness and appropriateness. Finally, all participants wrote a reflection paper about what and how they noticed about geometric constructions of parallels in individual learning process and GeoGebra-supported learning environment. The data were analyzed based on content analysis. Participants' compass-ruler constructions were examined to response the first research question, participants' verbal expressions in class discussion and written reflections were analyzed to answer the second research question.

\section{Results and Discussion}

The results showed that $38 \%$ of prospective teachers (PTs) used four different methods in appropriate parallelism constructions such as perpendicular lines, angle copying, equilateral triangles, and rhombus methods. They mostly used the methods of perpendicular lines and equilateral triangles in correct constructions. Another important result was that more than half of the prospective teachers did not achieve the appropriate geometric constructions because they made incorrect assumptions in the geometric constructions. This situation is consistent with the findings of previously conducted studies about geometric constructions because they conclude that teachers/prospective teachers have various difficulties in constructions of geometric shapes (Erduran \& Yeşildere, 2010; Karakuş, 2014; Öçal \& Şimşek, 2017). On the other hand, prospective teachers noticed following issues in classroom discussions in which dynamic geometry software was used: (a) alternative construction methods, (b) the necessity of providing solid foundations, (c) the effect of incorrect assumptions in geometric constructions, and (d) the roles of dynamic geometry software and compass-straightedge in geometric construction and justification process. Considering the contributions of both learning materials to geometric construction 
process, it is thought that using compass-ruler and dynamic geometry software at the same time will be useful in supporting prospective teachers' geometric construction skills in teacher education programs.

\section{Kaynaklar/References}

Abravanel, E. (1977). The figural simplicity of parallel lines. Child Development, 48(2), 708-710.

Altun, M. (2015). Liselerde matematik ögretimi. Bursa: Aktüel Yayınc1lık.

Axler, S., \& Ribet, K.A. (2005). Straightedge and compass. In J. Stillwell (Ed.), The four pillars of geometry (pp. 1-19). New York: Springer.

Baltacı, S., Yıldız, A., \& Kösa, T. (2015). The potential of GeoGebra dynamic mathematics software in teaching analytic geometry: The opinion of pre-service mathematics teachers. Turkish Journal of Computer and Mathematics Education, 6(3), 483-505.

Bektaş, M., Kahraman, S. ve Temel, Y. (2018). Matematik ders kitabı 6. Ankara: Milli Eğitim Bakanlı̆̆ı.

Bokosmaty, S., Mavilidi, M. F., \& Paas, F. (2017). Making versus observing manipulations of geometric properties of triangles to learn geometry using dynamic geometry software. Computers and Education, 113, 313-326.

Bozkurt, A. (2018). Examining the accuracy and justification of geometric constructions made by pre-service teachers with dynamic geometry software and the awareness they gained throughout the process. International Journal of Research in Education and Science, 4(1), 304-313.

Böge, H. ve Akıllı, R. (2018). Matematik 8 ders kitabı. Ankara: Milli Eğitim Bakanlığı.

Bu, L., \& Haciomeroglu, E. S. (2010). Sliders in dynamic mathematics learning environments: Their pedagogical roles. Mathematics and Computer Education, 44(3), 213-221.

Cherowitzo, B. (2006). Geometric constructions. Retrieved March 20, 2018 from http://www-math.cudenver.edu/ wcherowi/courses/m3210/lecchap5.pdf.

Cheung, L. H. (2011). Enhancing students' ability and interest in geometry learning through geometric constructions (Unpublished master's thesis). The University of Hong Kong, China.

Cohen, L., Manion, L., \& Morrison, K. (2002). Research methods in education. London: Routledge.

Collaborate, Plan, Align, Learn, Motivate, and Share [CPALMS]. (2019). Constructions of parallel lines. Retrieved November 18, 2018 from http://www.cpalms.org/Public/PreviewResourceAssessment/Preview/57411

Çiftçi, O. ve Tatar, E. (2014). Pergel-cetvel ve dinamik bir yazılım kullanımının başarıya etkilerinin karşılaştırılması. Journal of Computer and Education Research, 2(4), 111133.

De Villiers, M. (2003). Rethinking proof with geometer's sketchpad 4. Emeryville: Key Curriculum Press. 
Dikovich L. J. (2009). Applications GeoGebra into teaching some topics of mathematics at the college level. Computer Science and Information Systems, 6(2), 191-203.

Duval, R. (1998). Geometry form a cognitive point a view. In C. Mammana, \& V. Villani (Eds.), Perspectives on the teaching of geometry for the $21^{\text {st }}$ Century (pp. 37-52). Dordrecht, Boston: Kluwer Academic Publishers.

Erduran, A. ve Yesildere, S. (2010). Geometrik yapıların inşasında pergel ve çizgecin kullanımı. Illköğretim Online, 9(1), 331-345.

Freeman, C. M. (2010). Hands-on geometry: Constructions with straightedge and compass, grades 4-6. Waco, Texas: Prufrock Press.

Gal, H. (2011). From another perspective: Training teachers to cope with problematic learning situations in geometry. Educational Studies in Mathematics, 78(2), 183-203.

Güneş, G. ve Baki, A. (2011). Dördüncü sınıf matematik dersi öğretim programının uygulamasından yansımalar. Hacettepe Üniversitesi Ĕ̈itim Fakültesi Dergisi, 41, 192 205.

Gür, H. ve Kobak-Demir, M. (2017). Pergel-cetvel kullanarak temel geometrik çizimlerin öğretmen adaylarının geometrik düşünme düzeyleri. Eğitimde Kuram ve Uygulama, 13(1), 88-110.

Güven, Y. (2006). Farklı geometrik çizim yöntemleri kullanımının öğrencilerin başarı, tutum ve van hile geometri anlama düzeylerine etkisi (Yayınlanmamış yüksek lisans tezi). Karadeniz Teknik Üniversitesi, Fen Bilimleri Enstitüsü, Trabzon.

Hiebert, J., Carpenter, T. P., Fennema, E., Fuson, K. C., Wearne, D., Murray, H., Oliver, A., \& Human, P. (1997). The nature of classroom tasks. In Hiebert et. al. (Eds.), Making sense: Teaching and learning mathematics with understanding (pp. 17-28). Portsmouth, NH: Heinemann.

Hohenwarter, J., Hohenwarter, M., \& Lavicza, Z. (2010). Evaluating difficulty levels of dynamic geometry software tools to enhance teachers' professional development. International Journal for Technology in Mathematics Education, 17(3), $127-134$.

İşman, A. (2005). Öğretim teknolojileri ve materyal geliştirme. Ankara: Pegem Yayıncılık.

Jones, K. (2000). Providing a foundation for deductive reasoning: Students' interpretations when using dynamic geometry software. Educational Studies in Mathematics, 44, 5585.

Karakuş, F. (2014). İlköğretim matematik öğretmeni adaylarının geometrik inşa etkinliklerine yönelik görüşleri. Journal of Theoretical Educational Science, 7(4), 408435.

Knapp, L. R., \& Glenn, A. D. (1996). Restructuring schools with technology. Boston: Allyn and Bacon.

Kutluca, T. ve Zengin, Y. (2011). Matematik öğretiminde GeoGebra kullanımı hakkında öğrenci görüşlerinin değerlendirilmesi. Dicle Üniversitesi Ziya Gökalp Ĕ̌itim Fakültesi Dergisi, 17, 160-172.

Lim-Teo, S. K. (1997). Compass constructions: A vehicle for promoting relational understanding and higher order thinking skills. The Mathematics Educator, 2(2), 138 147. 
Mainali, B. R., \& Key, M. B. (2012). Using dynamic geometry software GeoGebra in developing countries: A case study of impressions of mathematics teachers in Nepal. International Journal for Mathematics Teaching and Learning, 12, 1-16.

Mansfield, H. M., \& Happs, J. C. (1992). Using grade eight students' existing knowledge to teach about parallel lines. School Science and Mathematics, 92(8), 450-454.

Milli Eğitim Bakanlığı [MEB]. (2009). İlköğretim matematik dersi 6-8. sinıflar öğretim programı ve kllavuzu. Ankara: MEB.

Milli Eğitim Bakanlığı [MEB]. (2018). Ilköğretim matematik dersi 6-8. sinıflar öğretim programı ve kllavuzu. Ankara: MEB.

Miles, M. B., \& Huberman, A. M. (1994). Qualitative data analysis: An expanded sourcebook. Beverly Hills: Sage Publications.

Mitchelmore, M. C. (1992). Why children do not draw parallels. In B. Southwell, B. Perry, \& K. Owens (Eds.) Proceedings of the 15th Annual Conference of the Mathematics Education Research Group or Australasia (pp.390-397), Richmond, New South Wale.

Napitupulu, B. (2001). An exploration of students' understanding and Van Hieles of thinking on geometric constructions (Unpublished master's thesis). Simon Fraser University, Canada.

National Council of Teachers of Mathematics [NCTM]. (2000). Principles and standards for school mathematics. Reston, VA: Author.

Öçal, M. F. ve Şimşek, M. (2017). Pergel-çizgeç ve Geogebra inşaları üzerine: Öğretmenlerin geometrik inşa süreçleri ve görüşleri. Gazi Üniversitesi Gazi Eğitim Fakültesi Dergisi, 37(1), 219-262.

Posamentier, A. S. (2000). Making geometry come alive: Student activities and teacher notes. California: Corwin Press.

Silverman, D. (2001). Interpreting qualitative data: Methods for analysing talk, text and interaction. London: SAGE Publication.

Smart, J. R. (1993). Modern geometries. Pacific Grove, Calif.: Brooks.

Spear-Swerling, L. (2006). The use of manipulatives in mathematics instruction. Retrieved June 21, 2006 from www.ldonline.org.

Stillwell, J. (2005). The four pillars of geometry. New York: Springer Science \& Business Media.

Tatar, E. (2013). The effect of dynamic software on prospective mathematics teachers' perceptions regarding information and communication technology. Australian Journal of Teacher Education, 38(12), 1-16.

Tatar, E., Kağızmanlı, T. B. ve Akkaya, A. (2014). Dinamik bir yazılımın çemberin analitik incelenmesinde başarıya etkisi ve matematik öğretmeni adaylarının görüşleri. Necatibey Eğitim Fakültesi Elektronik Fen ve Matematik Eğitimi Dergisi, 8(1), 153-177.

Ulusoy, F. (2016). The role of learners' example spaces in example generation and determination of two parallel and perpendicular line segments. In Csíkos, C., Rausch, A., \& Szitányi, J. (Eds.). Proceedings of the 40th Conference of the International Group for the Psychology of Mathematics Education (Vol. 4, pp. 299-306). Szeged, Hungary: PME. 
Ulusoy, F. ve Çakıroğlu, E. (2017). Ortaokul öğrencilerinin paralelkenarı ayırt etme biçimleri: Aşırı özelleme ve aşırı genelleme. Abant İzzet Baysal Eğitim Fakültesi Dergisi, 17(1), 457-475.

Weber, R. P. (1985). Basic content analysis, quantitative applications in the social sciences. Beverly Hills, CA: Sage Publications.

Yin, R. (2013). Case study research: Design and methods. London: Sage. 